\title{
29. COMPOSITIONS OF BASALTIC GLASSES FROM THE EAST PACIFIC RISE AND SIQUEIROS FRACTURE ZONE, NEAR $9^{\circ} \mathrm{N}$
}

\author{
James H. Natland, Deep Sea Drilling Project, Scripps Institution of Oceanography, University of California, \\ La Jolla, California \\ and \\ William G. Melson, Department of Mineral Sciences, Smithsonian Institution, Washington, D.C.
}

\begin{abstract}
The compositions of 45 natural basalt glasses from nine dredge stations and six Deep Sea Drilling Project Leg 54 sites near $9^{\circ} \mathrm{N}$ on the East Pacific Rise have been determined by electron microprobe. These comprise 19 distinct chemical groups. Seventeen of these fall in the range of the eastern Pacific tholeiite suite, which is characterized by marked enrichment in $\mathrm{FeO}^{*}, \mathrm{TiO}_{2}, \mathrm{~K}_{2} \mathrm{O}$, and $\mathrm{P}_{2} \mathrm{O}_{5}$ as $\mathrm{CaO}$, $\mathrm{MgO}$, and $\mathrm{Al}_{2} \mathrm{O}_{3}$ all decrease. Based on trace elements, an estimated 50-75 per cent fractionation of plagioclase, clinopyroxene, and olivine is required to produce ferrobasalts from parental olivine tholeiites. Additional chemical variations occur which require source heterogeneities, differences in the degree of melting, different courses of shallow fractionation, or magma mixing to explain. Glass compositions from within the Siqueiros fracture zone are mostly less fractionated than those from the flanks of the Rise, and show chemical differences which require variations in the depth of melting or highpressure fractionation to explain. Some of them could not be parental to East Pacific Rise flank ferrobasalts.

Two remaining glass groups, from dredge hauls atop a ridge and a seamount, respectively, have distinctly higher $\mathrm{K}_{2} \mathrm{O}, \mathrm{P}_{2} \mathrm{O}_{5}$, and $\mathrm{TiO}_{2}$ as well as lower $\mathrm{CaO} / \mathrm{Al}_{2} \mathrm{O}_{3}$ and $\mathrm{SiO}_{2}$ at corresponding values of $\mathrm{MgO}$ than the tholeiite suite. These abundances, and whole-rock $\mathrm{Y} / \mathrm{Zr}, \mathrm{Ce} / \mathrm{Y}, \mathrm{Nb} / \mathrm{Zr}$, and isotopic abundances indicate that these basalts had a deeper, less depleted mantle source than the Rise tholeiite suite. Trace element abundances preclude the "ridge" basalt type from being a hybrid between the "seamount" basalt type and any East Pacific Rise tholeiite so far analyzed.

The East Pacific Rise glasses from $9^{\circ} \mathrm{N}$ compare very closely to glasses dredged and drilled elsewhere on the East Pacific Rise. However, glass compositions from Site 424 on the Galapagos Rift drilled during Leg 54, as well as glasses and basalts dredged from the Galapagos and Costa Rica rifts, indicate that a greater degree of melting prevailed along much of the Galapagos Spreading Center than anywhere along the East Pacific Rise.
\end{abstract}

\section{INTRODUCTION}

In this chapter we present 45 new analyses of natural basaltic glasses primarily from dredge stations and Deep Sea Drilling Project Leg 54 drill sites from the East Pacific Rise and Siqueiros fracture zone near $9^{\circ} \mathrm{N}$. The analyses were obtained by electron microprobe on chips of glass obtained from the chilled outer rinds of pillows and flows. The purpose of the study was to provide a comprehensive suite of analyses of natural glasses from a restricted, but typical, portion of a fast-spreading ridge. Secondarily, this study was undertaken to provide an internally consistent set of data, analyzed by the same technique and standardized in the same way, for both dredge stations (including those of the Deepsonde Expedition site survey), and drill sites.

Natural glass compositions of sea-floor basalts have two advantages over whole-rock compositions. First, they are liquid compositions, unaffected by mechanical concentration of phenocrysts. Secondly, although they may have absorbed small amounts of water, they are otherwise unmodified by alteration processes; they have no clay or calcite veins, nor do they have uncharacteristically high $\mathrm{K}_{2} \mathrm{O}$. Previous experience with natural basalt glasses shows that they are homogeneous at the precision of electron microprobe analyses (e.g., Melson et al., 1976) and are therefore reliable indicators of the composition of eruptive units. They can be used both to dis- 
criminate chemical types otherwise blurred by the presence of phenocrysts (as we shall show in this report) and to show that some chemical types result entirely from different proportions of phenocrysts (Melson, 1978).

\section{PROCEDURES}

Samples were selected aboard the Glomar Challenger and from dredge hauls archived at the Scripps Institution of Oceanography. The sample selection for the DSDP materials was guided by the availability of glasses, and by identification of distinct petrographic types. The dredge sample selection was guided by published analyses and descriptions (Batiza et al., 1977; Johnson, 1979; Batiza and Johnson, this volume; Schrader et al., this volume). Of particular interest were olivine-spinel phyric oceanites (dredge SD-7, Siqueiros Expedition, Siqueiros fracture zone, described by Schrader et al., this volume), alkalic olivine basalts (dredge SD-8, Siqueiros Expedition, Siqueiros fracture zone, described by Batiza et al., 1977), and various $\mathrm{MgO}$-rich and $\mathrm{MgO}$-poor basalts that have been used elsewhere in fractionation and mixing calculations (Batiza et al., 1977; Batiza and Johnson, this volume).

Samples were analyzed on an ARL nine-channel microprobe housed at the Department of Mineralogy, Smithsonian Institution. A defocused beam of about 50 microns diameter, at 15 kilovolts and 30 microamperes beam current was used for all analyses. Defocusing the probe beam virtually eliminates sample volatilization. Standards used for $\mathrm{Si}, \mathrm{Al}, \mathrm{Fe}, \mathrm{Mg}, \mathrm{Ca}, \mathrm{Na}$, and $\mathrm{Ti}$ are fresh basaltic glass dredged from the Juan de Fuca Ridge (USNM111240/52; VG-2) and Smithsonian standard microcline and apatite for $\mathrm{K}$ and $\mathrm{P}$, respectively. In addition to matrix and drift corrections, the results are normalized every 10 analyses by running the basaltic glass standard. The internal standard is mounted in the center of an 1-inch plastic disk contain 10 unknowns around its rim, and eliminates variations caused, for example, by differing thickness of carbon coats. The homogeneity of glasses within chemical units judged to be discrete eruptive events has been shown to be comparable with, or less than, the precision obtained by repeated analyses obtained by classical techniques on the standard VG-2 (Melson, 1978). Some idea of sample homogeneity can be obtained from the average composition and standard deviation of 24 glass chips from a single dredge haul from the East Pacific Rise (PL-1, $3^{\circ} 25.5^{\prime} \mathrm{S}$, $102^{\circ} 35.7^{\prime} \mathrm{W}$; Lonsdale, 1977): $\mathrm{SiO}_{2}=51.52 \pm 0.34$ per cent, $\mathrm{Al}_{2} \mathrm{O}_{3}=13.82 \pm 0.17$ per cent. FeO* $=12.05$ \pm 0.13 per cent, $\mathrm{MgO}=6.20 \pm 0.12$ per cent, $\mathrm{CaO}=$ $10.57 \pm 0.08$ per cent, $\mathrm{Na}_{2} \mathrm{O}=2.96 \pm 0.05$ per cent, $\mathrm{K}_{2} \mathrm{O}=0.13 \pm 0.01$ per cent, $\mathrm{TiO}_{2}=1.97 \pm 0.05$ per cent, and $\mathrm{P}_{2} \mathrm{O}_{5}=0.18 \pm 0.02$ per cent. Values of twice the standard deviation ( $95 \%$ confidence limits) correspond closely to ranges for standard VG-2 and DSDP Hole 395A Unit $A_{3}$ given in Melson (1978).

\section{SAMPLE DISTRIBUTION}

Sample locations are given in Table 1 and shown on Figure 1. Most DSDP sites are clustered around OCP Ridge on crust between 1 and 2 m.y. old. Site 429 is on
TABLE 1

Locations of DSDP Sites, Dredge Hauls, From Which Glass Analyses Have Been Obtained

\begin{tabular}{cccl}
\hline Hole/Dredge & Latitude & Longitude & \multicolumn{1}{c}{ Location $^{\mathrm{b}}$} \\
\hline 420 & $09^{\circ} 00.10^{\prime} \mathrm{N}$ & $106^{\circ} 06.77^{\prime} \mathrm{W}$ & EPR Flank \\
421 & $09^{\circ} 01.41^{\prime} \mathrm{N}$ & $106^{\circ} 03.68^{\prime} \mathrm{W}$ & EPR Flank \\
423 & $09^{\circ} 08.81^{\prime} \mathrm{N}$ & $105^{\circ} 06.57^{\prime} \mathrm{W}$ & EPR Flank \\
$424 \mathrm{~A}$ & $00^{\circ} 35.33^{\prime} \mathrm{N}$ & $86^{\circ} 07.81^{\prime} \mathrm{W}$ & GR Flank \\
$424 \mathrm{C}$ & $00^{\circ} 35.93^{\prime} \mathrm{N}$ & $86^{\circ} 07.82^{\prime} \mathrm{W}$ & GR Flank \\
$428 \mathrm{~A}$ & $09^{\circ} 02.77^{\prime} \mathrm{N}$ & $105^{\circ} 26.14^{\prime} \mathrm{W}$ & Base, OCP Ridge \\
$429 \mathrm{~A}$ & $09^{\circ} 02.01^{\prime} \mathrm{N}$ & $106^{\circ} 45.87^{\prime} \mathrm{W}$ & EPR Flank \\
SD-3 & $08^{\circ} 23.0^{\prime} \mathrm{N}$ & $103^{\circ} 57.3^{\prime} \mathrm{W}$ & SFZ \\
SD-5 & $08^{\circ} 35.2^{\prime} \mathrm{N}$ & $104^{\circ} 17.3^{\prime} \mathrm{W}$ & EPR Crest \\
SD-6 & $08^{\circ} 21.5^{\prime} \mathrm{N}$ & $103^{\circ} 40.9^{\prime} \mathrm{W}$ & SFZ \\
SD-7 & $08^{\circ} 22.8^{\prime} \mathrm{N}$ & $103^{\circ} 40.9^{\prime} \mathrm{W}$ & SFZ \\
SD-8 & $08^{\circ} 23.8^{\prime} \mathrm{N}$ & $104^{\circ} 02.5^{\prime} \mathrm{W}$ & Seamount SFZ \\
DS-3 & $09^{\circ} 07.7^{\prime} \mathrm{N}$ & $105^{\circ} 07.6^{\prime} \mathrm{W}$ & EPR Flank \\
DS-4 & $09^{\circ} 07.0^{\prime} \mathrm{N}$ & $105^{\circ} 00.2^{\prime} \mathrm{W}$ & OCP Ridge \\
DS-5 & $09^{\circ} 12.6^{\prime} \mathrm{N}$ & $105^{\circ} 12.5^{\prime} \mathrm{W}$ & EPR Flank \\
\hline a Latitudes and longitudes of locations where dredges first touched \\
bottom only. \\
bPR = East Pacific Rise; GR = Galapagos Rift; SFZ = Siqueiros \\
fracture zone.
\end{tabular}

slightly older crust, about 4 m.y. old, to the west (East Pacific Rise Site Report, this volume). Samples were also obtained from three Deepsonde Expedition site survey dredge hauls. Two of these were to the north of OCP Ridge (DS-3 and DS-5), but the third (DS-4) was across its summit. Finally, samples were obtained from five Siqueiros Expedition dredge hauls. One of these (SD-5) was across the crest of the East Pacific Rise; all others (SD-3, SD-6, SD-7, and SD-8) were in the Siqueiros fracture zone. SD-6 and SD-7 dredge tracks crossed each other. SD-8 was on a small seamount within the fracture zone (Batiza et al., 1977).

\section{GLASS COMPOSITIONS}

The glass compositions of chips obtained from all these sample stations are listed in Table 2. At least two, and as many as 10 , glass chips from separate cooling units were analyzed for each DSDP site or dredge station. In addition to the East Pacific Rise samples, three glass chips from two holes at Site 424 on the Galapagos Rift $\left(00^{\circ} 35.3\right.$ and $\left.00^{\circ} 35.9 \mathrm{~N}, 86^{\circ} 07.8^{\prime} \mathrm{W}\right)$ are listed.

Many of the analyses from individual locations are clearly very similar. In order to determine how many chemical groups there are among these analyses, a sorting procedure similar to that described in Melson et al. (1976) was used (the principal difference being that here, the sorting of these relatively few analyses was done by inspection rather than computer). The oxide differences between analyses were compared to predetermined tolerances, given as follows, in weight per cent of oxide: $\mathrm{SiO}_{2}=1.10, \mathrm{Al}_{2} \mathrm{O}_{3}=0.80, \mathrm{FeO}^{*}=0.60$, $\mathrm{MgO}=1.00 . \mathrm{CaO}=0.60, \mathrm{Na}_{2} \mathrm{O}=0.30, \mathrm{~K}_{2} \mathrm{O}=0.08$, $\mathrm{TiO}_{2}=0.30$ and $\mathrm{P}_{2} \mathrm{O}_{5}=0.08$. Chemical groups were formed by combining analyses that satisfied the following two criteria: (1) each analysis in the group differed from every other analysis in the group by less than the stated tolerances for each of the nine oxides; and (2) all analyses in a group were from a single DSDP or dredge 


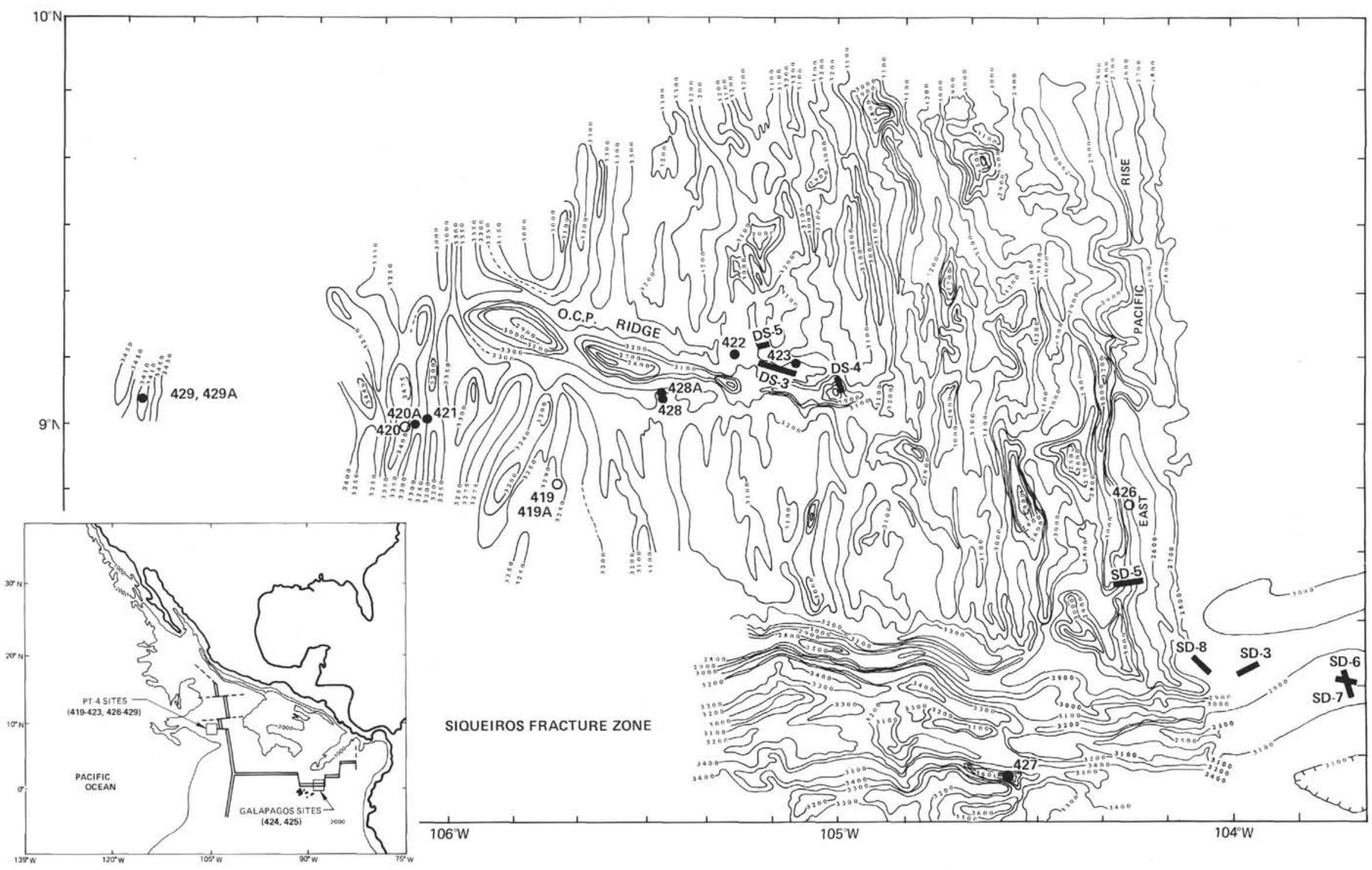

Figure 1. Locations of dredge stations (solid lines) and Leg 54 drill sites (filled and open circles) on the East Pacific Rise near $9^{\circ} N$ and in the Siqueiros fracture zone. Drill sites with no basalt recovery are shown by open circles. Dredge stations with no basalt recovery are not shown. Bathymetry by B. R. Rosendahl. Contour interval is 100 meters, except in trench where some contours have been omitted to prevent crowding. 
TABLE 2

Electron Microprobe Compositions of Glasses

\begin{tabular}{|c|c|c|c|c|c|c|c|c|c|c|c|}
\hline \multirow{2}{*}{$\begin{array}{l}\text { DSDP Sample } \\
\text { (distance below } \\
\text { top of section } \\
\text { in } \mathrm{cm} \text { ) }\end{array}$} & \multicolumn{11}{|c|}{ Dredge Sample } \\
\hline & $\mathrm{VG} \#$ & $\mathrm{SiO}_{2}$ & $\mathrm{Al}_{2} \mathrm{O}_{3}$ & $\mathrm{FeO} *$ & $\mathrm{MgO}$ & $\mathrm{CaO}$ & $\mathrm{Na}_{2} \mathrm{O}$ & $\mathrm{K}_{2} \mathrm{O}$ & $\mathrm{TiO}_{2}$ & $\mathrm{P}_{2} \mathrm{O}_{5}$ & Sum \\
\hline $420-14-1,49$ & 3214 & 50.61 & 14.05 & 11.76 & 6.48 & 11.11 & 2.70 & 0.15 & 2.04 & 0.18 & 99.08 \\
\hline $15-1,71$ & 3215 & 50.35 & 14.15 & 11.72 & 6.52 & 11.16 & 2.66 & 0.14 & 2.04 & 0.19 & 98.93 \\
\hline $421-3-1,37$ & 3216 & 50.35 & 14.27 & 12.09 & 6.27 & 11.00 & 2.82 & 0.14 & 2.16 & 0.18 & 99.28 \\
\hline $3-1,101$ & 3217 & 50.52 & 14.07 & 12.19 & 6.22 & 11.03 & 2.73 & 0.15 & 2.14 & 0.19 & 99.24 \\
\hline $3-1,116$ & 3218 & 50.30 & 14.20 & 12.19 & 6.12 & 11.08 & 2.82 & 0.17 & 2.10 & 0.21 & 99.19 \\
\hline $423-5, \mathrm{CC}(21)$ & 3220 & 50.49 & 13.87 & 11.96 & 6.59 & 10.90 & 2.80 & 0.15 & 2.16 & 0.20 & 100.12 \\
\hline $8-1,2$ & 3221 & 50.29 & 13.79 & 11.99 & 6.50 & 10.96 & 2.86 & 0.15 & 2.21 & 0.24 & 98.99 \\
\hline $424 \mathrm{~A}-4-1,41$ & 3222 & 51.16 & 13.07 & 13.70 & 5.92 & 10.59 & 2.41 & 0.07 & 1.84 & 0.16 & 98.92 \\
\hline $424 C \cdot 2-1,49$ & 3223 & 50.82 & 12.98 & 13.69 & 5.93 & 10.57 & 2.33 & 0.07 & 1.86 & 0.13 & 98.38 \\
\hline $3-1,2$ & 3224 & 50.85 & 13.06 & 13.90 & 6.16 & 10.67 & 2.40 & 0.07 & 1.88 & 0.16 & 99.15 \\
\hline $428 \mathrm{~A}-1-1,12$ & 3225 & 50.82 & 14.75 & 9.90 & 7.28 & 12.13 & 2.71 & 0.14 & 1.51 & 0.15 & 99.39 \\
\hline $1-4,44$ & 3226 & 50.82 & 14.74 & 9.80 & 7.27 & 12.15 & 2.72 & 0.12 & 1.47 & 0.15 & 99.24 \\
\hline $429 A-2-1,8$ & 3227 & 50.06 & 15.35 & 9.36 & 8.03 & 12.66 & 2.62 & 0.06 & 1.24 & 0.10 & 99.48 \\
\hline $2-1,20$ & 3228 & 49.77 & 15.23 & 9.26 & 7.88 & 12.66 & 2.61 & 0.07 & 1.22 & 0.10 & 98.80 \\
\hline $2-1,100$ & 3229 & 49.60 & 14.18 & 11.10 & 6.85 & 11.28 & 2.72 & 0.12 & 1.72 & 0.15 & 97.72 \\
\hline \multicolumn{12}{|c|}{ Dredge Sample No. } \\
\hline DS-3-1 & 3863 & 50.94 & 14.53 & 10.60 & 6.84 & 11.39 & 2.88 & 0.16 & 1.83 & 0.20 & 99.37 \\
\hline DS-3-3A & 3864 & 49.31 & 17.60 & 7.95 & 9.06 & 12.37 & 2.44 & 0.04 & 0.96 & 0.09 & 99.82 \\
\hline DS-3-3B & 3865 & 49.10 & 17.48 & 7.98 & 9.17 & 12.32 & 2.42 & 0.04 & 0.98 & 0.08 & 99.57 \\
\hline DS-3-6A & 3866 & 51.02 & 13.98 & 11.23 & 6.17 & 10.22 & 3.10 & 0.22 & 2.12 & 0.30 & 99.36 \\
\hline DS-3-6B & 3867 & 51.44 & 14.13 & 11.23 & 6.24 & 10.36 & 3.16 & 0.23 & 2.13 & 0.31 & 99.22 \\
\hline DS-3-7 & 3868 & 50.32 & 14.31 & 10.45 & 6.79 & 11.18 & 2.85 & 0.15 & 1.78 & 0.22 & 98.05 \\
\hline DS-4-2 & 3869 & 51.12 & 15.52 & 9.30 & 7.70 & 12.12 & 2.56 & 0.18 & 1.36 & 0.14 & 100.00 \\
\hline DS-4-6 & 3747 & 48.99 & 16.72 & 9.12 & 7.88 & 10.64 & 3.19 & 0.35 & 1.88 & 0.25 & 99.02 \\
\hline DS-4-14 & 3748 & 49.16 & 16.87 & 8.97 & 7.76 & 10.65 & 3.22 & 0.35 & 1.92 & 0.24 & 99.14 \\
\hline DS-5-5 & 3749 & 50.73 & 13.63 & 12.61 & 6.24 & 10.65 & 2.86 & 0.16 & 2.32 & 0.20 & 99.40 \\
\hline SD-3 Gl & 4240 & 50.17 & 16.04 & 9.23 & 8.46 & 12.38 & 2.15 & 0.09 & 1.18 & 0.11 & 99.81 \\
\hline SD-3 G2 & 4241 & 50.55 & 15.98 & 9.20 & 8.52 & 12.41 & 2.15 & 0.09 & 1.21 & 0.10 & 100.21 \\
\hline SD-3 G3 & 4242 & 50.58 & 15.97 & 9.25 & 8.53 & 12.34 & 2.17 & 0.08 & 1.21 & 0.11 & 100.24 \\
\hline SD-5 G1 & 4243 & 51.26 & 14.41 & 10.58 & 6.95 & 11.63 & 2.81 & 0.17 & 1.61 & 0.18 & 99.60 \\
\hline SD-5 G2 & 4244 & 51.11 & 14.50 & 10.48 & 6.83 & 11.55 & 2.86 & 0.20 & 1.63 & 0.15 & 99.31 \\
\hline SD-6 G1 & 4245 & 50.67 & 15.48 & 9.03 & 8.36 & 13.10 & 2.04 & 0.06 & 1.04 & 0.09 & 99.87 \\
\hline G2 & & & & & 8.41 & & & & & 0.11 & 99.56 \\
\hline $7 \mathrm{G1}$ & 4247 & 50.19 & 16.39 & 8.72 & 8.76 & 12. & 2.39 & 0.06 & 1. & 0.10 & 99.93 \\
\hline SD-7 G2 & 4248 & 48.75 & 17.03 & 10.01 & 8.18 & 11. & 2.73 & 0. & 1.39 & 0.12 & 99.71 \\
\hline SD-7 G3 & 4249 & 48.75 & 17.26 & 10.03 & 8.01 & 11.56 & 2.76 & 0.08 & 1.39 & 0.11 & 99.95 \\
\hline SD-7 G4 & 4250 & 48.48 & 17.11 & 10.08 & 8.06 & 11.16 & 2.82 & 0.08 & 1.44 & 0.08 & 99.31 \\
\hline SD-7 G5 & 4269 & 48.72 & 17.16 & 10.10 & 8.06 & & 2.82 & 0.09 & 1.42 & 0.13 & \\
\hline SD-7 G6 & 4251 & 50.46 & 16.56 & 8.90 & 8.57 & & & 0.06 & 1.21 & 0.08 & 100.33 \\
\hline SD-7 G7 & 4252 & 48.81 & 16.91 & 10.11 & 8.00 & 11 & 2.81 & 0.09 & 1.43 & 0.10 & 99.59 \\
\hline SD-7 G8 & 4253 & 50.17 & 16.76 & 8.81 & 8.65 & 12.23 & 2.46 & 0.07 & 1.23 & 0.10 & 100.48 \\
\hline SD-7 G9 & 4254 & 48.73 & 16.90 & 10.07 & 8.09 & 11.19 & 2.80 & 0.08 & 1.45 & 0.10 & 99.41 \\
\hline SD-7 ED & 4980 & 49.15 & 17.58 & 8.01 & 9.58 & 12.14 & 2.38 & 0.04 & .96 & 0.10 & 99.94 \\
\hline SD-8 G1 & 4255 & 49.55 & 16.78 & 9.96 & 5.67 & 9.51 & 3.62 & 1.09 & 2.67 & 0.44 & 99.29 \\
\hline SD-8 G2 & 4256 & 49.55 & 16.73 & 9.82 & 5.81 & 9.54 & 3.62 & 1.10 & 2.73 & 0.42 & 99.32 \\
\hline SD- 8 G3 & 4257 & 49.71 & 16.68 & 9.87 & 5.86 & 9.56 & 3.66 & 1.11 & 2.67 & 0.45 & 99.57 \\
\hline
\end{tabular}

Note: All iron as $\mathrm{FeO}^{*}$.

site. Averages of the groups were compiled as well as standard deviations where more than two analyses were involved, and these are listed along with CIPW norms in Table 3. In all, there are 19 groups for the East Pacific Rise, and one for the Galapagos Rift. For convenience, and for the purpose of plotting, these are designated alphabetically in the order listed in Table 3.

For the large number of groups calculated by Melson et al. (1976), a further sorting procedure-to see whether groups not at the same location are equivalent-was used, with the oxide differences compared to tolerances of half those just listed. Such equivalences have been considered "a conservative measure of possible repetitions of chemical type within and among ocean basins", (Melson et al., 1976, p. 360). The same procedure employed here reveals no equivalence within the two dredge stations which crossed each other (SD-6 and SD-7, Groups C, D, E, and F), although the groups are very similar; it shows, however, two equivalences among the DSDP sites and one between two dredge sta- tions. Group N (Site 420) and Group O (Site 421) are each equivalent to Group P (Site 423) but not to each other (although they fail being equivalent to each other by only one oxide, $\mathrm{CaO}$ ). Group $\mathrm{F}$ (dredge SD-7) is equivalent to Group $\mathrm{H}$ (dredge DS-3). One other very near equivalence, between Group B (dredge SD-5) and Group I (dredge DS-3), fails in only two oxides. The glass analyses from $3^{\circ} \mathrm{S}$ on the East Pacific Rise listed earlier (Group U on Table 3) are also very similar to Groups N, O, and P (Sites 420-423). These equivalences, and near-equivalences, can better be appreciated by inspection of the $\mathrm{MgO}$ variation diagrams plotted as Figure 2.

Melson et al. (1976) used several informal designations to characterize the groups they defined. These designations were based on comparison with various averages of mid-ocean ridge basalt (MORB, Kay et al., 1970; Engel et al., 1965; Cann, 1970). Thus FETI basalts were higher in $\mathrm{FeO}^{*}$ and $\mathrm{TiO}_{2}$ than typical MORB; MGCA basalts were higher in $\mathrm{MgO}$ and $\mathrm{CaO}$, and $\mathrm{KP}$ 
basalts were higher in $\mathrm{K}_{2} \mathrm{O}$ and $\mathrm{P}_{2} \mathrm{O}_{5}$ but not necessarily $\mathrm{FeO}^{*}$ and $\mathrm{TiO}_{2}$. In this regard, most of the groups of Table 3 which we have described as equivalent, or nearly equivalent, are FETI basalts or very nearly so (Groups $\mathrm{N}, \mathrm{O}, \mathrm{P}, \mathrm{B}, \mathrm{I}$, and U). The compilation of Melson et al. (1976) demonstrated a clear tendency for iron- and titanium-enriched basalts to occur on the East Pacific Rise, but not the Mid-Atlantic Ridge. The other Pacific Ocean equivalences identified in that paper were primarily among basalts of the Juan de Fuca Ridge, several of them FETI compositions. A surprising conclusion of this work, then, is that, in the Siqueiros study area, basalts which erupted at the Rise crest between fracture zones not only tend to have FETI compositions, but those which erupted at different times at practically the same point along the Rise crest (Sites 420,421 , and 423) have virtually identical FETI compositions. This also seems to be the case for the Juan de Fuca Ridge.

The other rock designations, MGCA and KP, are not without their representatives in the Siqueiros region. Groups F (dredge SD-7) and H (dredge DS-3) are similar to $\mathrm{MgO}$ - and $\mathrm{CaO}$-rich glasses from DSDP Leg 3 in the South Atlantic (sample groups A28.33S1 and A27.99S1 of Melson, et al., 1976, Table 3). All the samples from dredge SD-7 (Groups D, E, and F) came from rocks with abundant olivine and spinel phenocrysts (Schrader et al., this volume; Natland, Crystal Morphologies chapter, this volume), although glass Groups D and E do not have as much $\mathrm{MgO}$ and $\mathrm{CaO}$ as Groups $\mathrm{F}$ and $\mathrm{H}$. There are clearly three groups within dredge SD-7, but none of these resembles the single glass analysis from this dredge listed in Schrader et al. (this volume). That analysis, which has over 11 per cent $\mathrm{MgO}$, nevertheless has such low $\mathrm{Na}_{2} \mathrm{O}$ that we suspect some volatilization occurred affecting the analysis. Dr. Schrader was kind enough to supply us with an example of one of his most magnesian samples, agreeing that the earlier analysis was suspect. That example is glass Group F. Although its $\mathrm{MgO}$ is only 9.58 per cent, and discounting the analysis in Schrader et al. (this volume), this is still the most magnesian glass ever analyzed from the East Pacific Rise or its fracture zones. Despite this, by the criteria listed earlier, Groups F and $\mathrm{H}$ are compositionally equivalent. Therefore, in addition to the equivalences and near-equivalences among FETI compositions, at the other end of the compositional spectrum we have an equivalence among MGCA compositions, between a glass group from the Siqueiros fracture zone and one from the flanks of the East Pacific Rise.

The KP glasses from the Siqueiros region (Group G, dredge SD-8, and Group L, dredge DS-4) are both from the tops of seamounts. The Group G samples are from a small seamount in the Siqueiros fracture zone (Batiza et al., 1977) and the Group L samples from across the top of OCP Ridge (Figure 1), about $120 \mathrm{~km}$ away. Wholerock compositions from dredge SD-8 have higher $\mathrm{MgO}$ than the glasses reported here, and nepheline in the norm, hence are termed alkalic basalts by Batiza et al. (1977). Basalts of dredge DS-4, whose glasses comprise Group L, are intermediate in major oxide abundances, $\mathrm{Sr}$ and Nd-isotope ratios (Carlson, et al., 1978), and most trace elements between dredge SD- 8 basalts and primitive (MgO-rich) tholeiitic basalt compositions, but are not true alkalic basalts. Hence, they have been termed "transitional" basalts by Johnson (1979) and Batiza and Johnson (this volume). These authors propose that mixing occurred between alkalic basalt and primitive olivine tholeiites to produce the DS-4 basalts. From Tables 2 and 3, and Figure 2, it is evident that the Groups $\mathrm{G}$ and $\mathrm{L}$ glasses have considerably higher $\mathrm{Na}_{2} \mathrm{O}, \mathrm{K}_{2} \mathrm{O}$, $\mathrm{P}_{2} \mathrm{O}_{5}$, and $\mathrm{TiO}_{2}$ than all other glasses at comparable $\mathrm{MgO}$. They are also lower in $\mathrm{SiO}_{2}$ and have lower $\mathrm{CaO} / \mathrm{Al}_{2} \mathrm{O}_{3}$ (Figure 3). However, neither glass group has nepheline in the norm (Table 3). In the case of Group $\mathrm{G}$ the lack of nepheline in its norm, compared with the whole-rock norms of Batiza et al. (1977), cannot be accounted for simply by additional olivine in the wholerock compositions; some difference in analytical procedure (probably standardizaton is also required.

Rather than single out distinct chemical types, however it is more accurate to say that there are two fundamentally different rock suites on this segment of the East Pacific Rise. That which characterizes the Rise crest, and fault scarps plus ponded lavas in the Siqueiros fracture zone, is the Rise tholeiite suite, and is by far the most voluminous. It includes MGCA and FETI glasses at each end of a continuous spectrum of compositions. Within this suite, as $\mathrm{TiO}_{2}, \mathrm{~K}_{2} \mathrm{O}, \mathrm{P}_{2} \mathrm{O}_{5}, \mathrm{Na}_{2} \mathrm{O}$, and $\mathrm{FeO}^{*}$ all increase, $\mathrm{CaO}, \mathrm{Al}_{2} \mathrm{O}_{3}$, and $\mathrm{MgO}$ decrease. Since most of the glass samples here come from aphyric basalts, they closely approximate whole-rock compositions. These chemical variations are identical to those which have been simulated by models of crystal fractionation invoking separation of plagioclase, clinopyroxene, and olivine in decreasing order of abundance (Clague and Bunch, 1976; Batiza et al., 1977).

The second suite is that of the seamounts. These basalts require an isotopically and geochemically less depleted mantle source than that of the Rise tholeiite suite, according to Johnson (1979) and Batiza and Johnson (this volume). The volume of these basalts must be insignificant when compared with the Rise tholeiites, and their distinctive location atop seamounts on very young oceanic crust ( $\sim 2$ m.y.) confirms the earliest conceptions of the relationship between alkalic basalts and oceanic tholeiites (Engel and Engel, 1964, Engel et al., 1965). The soundness of this original perception can be appreciated from the inadvertent test of it that was made during Leg 54. Because of poor drilling conditions in basalts erupted from the Rise crest, and now distributed in faulted terrain along its flanks, the Leg 54 scientific party was forced to find ponded, more massive, basalts, to improve drill-string penetration and recovery. Sites 422 and 428 were drilled at two such locations in the moat-like structure adjacent to OCP Ridge (Figure 1). Neither the glasses from Site 428 (Group Q) nor basalts from Sites 422 and 428 (e.g., Joron et al., this volume; Humphris et al., this volume) have any of the geochemical characteristics of the seamount alkalic and transitional basalt suite. In fact, tholeiite suite glasses (Group K) were recovered in the same dredge (DS-4) which includes the "transitional" glasses (Group L). 
TABLE 3

Average Glass Group Compositions, Standard Deviations, and CIPW Norms

\begin{tabular}{|c|c|c|c|c|c|c|c|c|c|c|c|}
\hline \multirow{2}{*}{\multicolumn{2}{|c|}{$\begin{array}{l}\text { Group } \\
\text { Dredge or } \\
\text { Sitec }\end{array}$}} & A & B & C & D & E & F & G & $\mathrm{H}$ & 1 & J \\
\hline & & $\mathrm{SD} \cdot 3(3)$ & $S D-5(3)$ & $S D-6(2)$ & $\mathrm{SD} 7-\mathrm{A}(6)$ & $\mathrm{SD} 7-\mathrm{B}(3)$ & SD7 - C (1) & $S D-8(3)$ & DS3 - 3(2) & DS $3-1(2)$ & DS $3-6(2)$ \\
\hline \multicolumn{2}{|c|}{$\mathrm{SiO}_{2}$} & $50.43 \pm 0.23$ & 51.19 & 50.48 & $48.71=0.12$ & $50.27 \pm 0.16$ & 49.15 & $49.60 \pm 0.09$ & 49.21 & 50.63 & 51.23 \\
\hline \multicolumn{2}{|c|}{$\mathrm{Al}_{2} \mathrm{O}_{3}$} & $16.00 \pm 0.04$ & 14.46 & 15.43 & $17.06 \pm 0.14$ & $16.57 \pm 0.19$ & 17.58 & $16.73 \div 0.05$ & 17.54 & 14.42 & 14.06 \\
\hline $\mathrm{FeO}^{\circ}$ & & $9.23=0.03$ & 10.53 & 9.01 & $10.07=0.04$ & $8.81=0.09$ & 8.01 & $9.88 \pm 0.07$ & 7.97 & 10.53 & 11.23 \\
\hline \multicolumn{2}{|c|}{$\mathrm{MgO}$} & $8.50 \pm 0.04$ & 6.89 & 8.39 & $8.07 \pm 0.07$ & $8.66 \pm 0.10$ & 9.58 & $5.78=0.10$ & 9.12 & 6.62 & 6.21 \\
\hline \multicolumn{2}{|l|}{$\mathrm{CaO}$} & $12.38 \div 0.04$ & 11.59 & 13.17 & $11.33 \pm 0.15$ & $12.12 \pm 0.10$ & 12.14 & $9.54=0.03$ & 12.35 & 11.29 & 10.29 \\
\hline \multicolumn{2}{|c|}{$\mathrm{Na}_{2} \mathrm{O}$} & $2.16 \pm 0.01$ & 2.84 & 2.05 & $2.76 \pm 0.05$ & $2.44 \pm 0.04$ & 2.38 & $3.63=0.02$ & 2.43 & 2.87 & 3.13 \\
\hline \multicolumn{2}{|c|}{$\mathrm{K}_{2} \mathrm{O}$} & $0.09 \pm 0.01$ & 0.20 & 0.07 & $0.08 \pm 0.01$ & $0.06 \pm 0.01$ & 0.04 & $1.10=0.01$ & 0.04 & 0.16 & 0.23 \\
\hline \multicolumn{2}{|c|}{$\mathrm{TiO}_{2}$} & $1.20 \pm 0.02$ & 1.62 & 1.04 & $1.42 \pm 0.03$ & $1.22 \pm 0.01$ & 0.96 & $2.69=0.03$ & 0.97 & 1.81 & 2.12 \\
\hline \multirow{2}{*}{\multicolumn{2}{|c|}{$\begin{array}{l}\mathrm{P}_{2} \mathrm{O}_{5} \\
\mathrm{Mg} \text { \#政 }\end{array}$}} & $0.11 \div 0.01$ & 0.17 & 0.10 & $0.11 \pm 0.02$ & $0.09 \pm 0.01$ & 0.10 & $0.44 \pm 0.02$ & 0.09 & 0.21 & 0.31 \\
\hline & & $0.621(0.656)$ & $0.538(0.575)$ & $0.624(0.659)$ & $0.588(0.624)$ & $0.637(0.671)$ & $0.681(0.712)$ & $0.510(0.548)$ & $0.671(0.703)$ & $0.528(0.566)$ & $0.496(0.534)$ \\
\hline \multicolumn{12}{|c|}{ CIPW Norms ${ }^{b}$} \\
\hline \multicolumn{2}{|l|}{ q } & 0.00 & 0.00 & 0.00 & 0.00 & 0.00 & 0.00 & 0.00 & 0.00 & 0.30 & 1.21 \\
\hline \multirow{2}{*}{\multicolumn{2}{|c|}{$\begin{array}{l}\mathrm{c} \\
\text { or }\end{array}$}} & 0.00 & 0.00 & 0.00 & 0.00 & 0.00 & 0.00 & 0.00 & 0.00 & 0.00 & 0.00 \\
\hline & & 0.53 & 1.18 & 0.41 & 0.47 & 0.35 & 0.24 & 6.49 & 0.24 & 0.94 & 1.39 \\
\hline \multicolumn{2}{|l|}{$a b$} & 18.26 & 24.01 & 17.33 & 23.34 & 20.63 & 20.12 & 30.69 & 20.55 & 24.27 & 26.47 \\
\hline \multicolumn{2}{|l|}{ an } & 33.68 & 26.10 & 32.68 & 33.91 & 34.06 & 37.15 & 26.09 & 36.81 & 25.98 & 23.62 \\
\hline \multicolumn{2}{|l|}{ ne } & 0.00 & 0.00 & 0.00 & 0.00 & 0.00 & 0.00 & 0.00 & 0.00 & 0.00 & 0.00 \\
\hline \multicolumn{2}{|l|}{ wo ! } & 11.26 & 12.62 & 13.34 & 8.99 & 10.61 & 9.36 & 7.65 & 9.94 & 11.95 & 10.59 \\
\hline \multirow{2}{*}{$\left.\begin{array}{l}\text { en } \\
\text { fs }\end{array}\right\}$} & di & 6.82 & 6.91 & 8.07 & 5.25 & 6.58 & 6.12 & 4.28 & 6.38 & 6.51 & 5.54 \\
\hline & & 3.80 & 5,24 & 4.52 & 3.30 & 3.39 & 2.58 & 3.05 & 2.88 & 5.01 & 4.73 \\
\hline \multirow{2}{*}{$\begin{array}{l}\text { en } \\
\mathrm{fs}\end{array}$} & hy & 12.23 & 10.02 & 11.45 & 4.13 & 9.37 & 6.06 & 0.92 & 5.37 & 0.92 & 9.87 \\
\hline & hy & 6.80 & 7.60 & 6.42 & 2.60 & 4.82 & 2.56 & 0.65 & 2.43 & 7.63 & 8.43 \\
\hline \multirow{2}{*}{$\begin{array}{l}\text { fo } \\
\text { fa }\end{array}$} & ol & 1.42 & 0.11 & 0.91 & 7.45 & 3.87 & 8.11 & 6.40 & 7.61 & 0.00 & 0.00 \\
\hline & or & 0.87 & 0.10 & 0.56 & 5.18 & 2.20 & 3.78 & 5.04 & 3.80 & 0.00 & 0.00 \\
\hline \multicolumn{2}{|l|}{$\mathrm{mt}$} & 1.90 & 2.16 & 1.85 & 2.07 & 1.81 & 1.81 & 2.04 & 1.64 & 2.17 & 2.32 \\
\hline \multicolumn{2}{|l|}{ il } & 2.28 & 3.08 & 1.98 & 2.70 & 2.32 & 1.83 & 5.12 & 1.85 & 3.44 & 4.03 \\
\hline \multicolumn{2}{|l|}{ ap } & 0.25 & 0.38 & 0.23 & 0.25 & 0.21 & 0.23 & 1.02 & 0.21 & 0.49 & 0.72 \\
\hline \multicolumn{2}{|l|}{$\Sigma$} & 100.11 & 99.52 & 99.75 & 99.64 & 100.24 & 99.95 & 99.45 & 99.71 & 98.59 & 98.87 \\
\hline
\end{tabular}

${ }^{\mathrm{M}} \mathrm{Mg}=\mathrm{Mg}^{2+} /\left(\mathrm{Mg}^{2+}+\mathrm{Fe}^{2+}\right)$; first number has all iron as $\mathrm{Fe}^{2+}$, second uses $0.86 \mathrm{FeO} *$ to calculate $\mathrm{Fe}^{2+}$.

Calculated assuming $\mathrm{Fe}^{2+} /\left(\mathrm{Fe}^{2+}+\mathrm{Fe}^{3+}\right)=0.86$

${ }^{c}$ Parentheses enclose number of samples in group.

A major concern at the outset of Leg 54 was whether volcanism along OCP Ridge had reached the location of the ocean-bottom seismometer refraction station at the original principal target of the leg (Site 423). We have already seen that the glasses recovered at Site 423 (Group P) have iron- and titanium-enriched compositions virtually identical to basalts drilled at Sites 420 and 421 (Groups N and O), well away from OCP Ridge. There is therefore every petrologic indication that the geophysical experiment was conducted over a typical flank location of the East Pacific Rise. Evidently, "transitional" volcanism on OCP Ridge did not produce flows that reached even the base of that structure.

\section{INTEGRATION OF TRACE-ELEMENT AND GLASS-COMPOSITION DATA}

The abundant trace element data obtained on Leg 54 basalts by several laboratories (Joron et al., this volume; Humphris et al., this volume; Srivastava et al., this volume), plus trace element data on dredge samples (Johnson, 1979; Batiza and Johnson, this volume) make it possible to combine glass composition data and trace element abundances into single discussion of the relative roles of various magmatic processes in producing the two East Pacific Rise basalt suites.

Data for the trace elements $\mathrm{Ni}, \mathrm{Sr}$, and $\mathrm{Zr}$ had been obtained on several of the site survey (Deepsonde Expedition) dredged basalts using X-ray fluorescence and atomic absorption techniques by one of the authors ( $\mathrm{J}$. N.) in colloboration with J. Johnson prior to Leg 54 . The purpose of this was to establish "geochemical discriminants" between the Rise tholeiite and seamount alkalic basalt suites, in order to evaluate the petrologic character of basalts drilled at Site 423-the location of the ocean-bottom seismometer geophysical array. This evaluation was a critical part of the original drilling strategy adopted for Leg 54 (see Rosendahl et al., Chapter 1 , this volume).

Comparison of the $\mathrm{Sr}$ and $\mathrm{Zr}$ data of the dredged samples with those from the drilled basalts suggested that $\mathrm{Sr}$ data obtained on the dredged samples (determined by atomic absorption and reported in Johnson, 1979) were systematically low, providing an inadequate elemental interference correction for $\mathrm{Zr}$ (measured by $\mathrm{X}$-ray fluorescence on the $\mathrm{K}_{\alpha}$ peak). Following completion of Leg 54, arrival of a new Phillips 1410 X-ray fluorescence spectrometer at Scripps Institution to replace the venerable equipment on which the original measurements had been made, prompted the first author of this paper to redetermine $\mathrm{Sr}, \mathrm{Ni}$, and $\mathrm{Zr}$ on the dredge samples, this time all by XRF, as well as measure $\mathrm{Y}, \mathrm{Nb}$, and $\mathrm{Rb}$. These data are listed in Table 4. The matrix correction procedures used were modified somewhat from Bougault et al. (1977), and were based on the whole-rock analyses in Batiza et al., (1977) and Johnson (1979). The elemental interferences were corrected following the "cascade" procedure of Cann (1970 and 1970 manuscript). Standards were USGS and French international reference standards (Flanagan, 1973) plus several standards from DSDP Leg 45 (Natland et al., 1978) using the data of Centre Océanologique de Bretagne (COB). The results of the calibration, and comparisons of the data obtained on the Leg 45 standards with the $\mathrm{COB}$ data are given in Table 5 . Because the matrix correction and standardization procedures are so similar to those of the COB laboratory, comparisons here between trace elements in dredged samples and in Leg 54 basalts are mainly to data in Joron et al. (this volume). The new data confirm the error in the original $\mathrm{Sr}$ determinations, which resulted in $\mathrm{Zr}$ values too high 
TABLE 3 - Continued

\begin{tabular}{|c|c|c|c|c|c|c|c|c|c|c|}
\hline K & L & M & $\mathrm{N}$ & o & $\mathbf{P}$ & $Q$ & $\mathbf{R}$ & s & $\mathrm{T}$ & $\mathrm{U}$ \\
\hline DS4 - 2(1) & DS4 - 6(2) & DS5 - 5(1) & $420(2)$ & $421(3)$ & $423(2)$ & $428(2)$ & $429-1(2)$ & $429-2(1)$ & $424(3)$ & $\mathrm{PL}-1,3^{\circ} \mathrm{S}(24)$ \\
\hline 51.12 & 49.08 & 50.73 & 50.48 & $50.39 \div 0.12$ & 50.39 & 50.82 & 49.92 & 49.60 & $50.94=0.19$ & $51.52 \pm 0.34$ \\
\hline 15.52 & 16.80 & 13.63 & 14.10 & $14.18 \pm 0.10$ & 13.83 & 14.75 & 15.29 & 14.18 & $13.04 \pm 0.04$ & $13.82 \pm 0.17$ \\
\hline 9.30 & 9.05 & 12.61 & 11.74 & $12.16 \pm 0.06$ & 11.98 & 9.80 & 9.31 & 11.10 & $13.76 \pm 0.12$ & $12.05 \pm 0.13$ \\
\hline 7.70 & 7.82 & 6.24 & 6.50 & $6.20=0.08$ & 6.55 & 7.28 & 7.96 & 6.85 & $6.00=0.14$ & $6.20 \pm 0.12$ \\
\hline 12.12 & 10.65 & 10.65 & 11.14 & $11.04 \pm 0.04$ & 10.93 & 12.14 & 12.66 & 11.28 & $10.61 \pm 0.05$ & $10.57 \pm 0.08$ \\
\hline 2.56 & 3.21 & 2.86 & 2.68 & $2.79 \pm 0.05$ & 2.83 & 2.72 & 2.62 & 2.72 & $2.38 \pm 0.04$ & $2.96 \pm 0.05$ \\
\hline 0.18 & 0.35 & 0.16 & 0.15 & $0.15=0.02$ & 0.15 & 0.13 & 0.07 & 0.12 & $0.07 \div 0.00$ & $0.13 \pm 0.01$ \\
\hline 1.36 & 1.90 & 2.32 & 2.04 & $2.13 \pm 0.03$ & 2.19 & 1.49 & 1.23 & 1.72 & $1.86 \pm 0.02$ & $1.97 \pm 0.05$ \\
\hline 0.14 & 0.25 & 0.20 & 0.19 & $0.19 \pm 0.02$ & 0.22 & 0.15 & 0.10 & 0.15 & $0.14 \pm 0.02$ & $0.18 \pm 0.02$ \\
\hline $0.596(0.632)$ & $0.606(0.642)$ & $0.469(0.506)$ & $0.497(0.534)$ & $0.476(0.514)$ & $0.493(0.531)$ & $0.570(0.606)$ & $0.604(0.639)$ & $0.524(0.561)$ & $0.437(0.475)$ & $0.478(0.516)$ \\
\hline \multicolumn{11}{|c|}{ CIPW Norms ${ }^{b}$} \\
\hline 0.00 & 0.00 & 1.12 & 0.95 & 0.62 & 0.43 & 0.00 & 0.00 & 0.00 & 3.48 & 1.64 \\
\hline 0.00 & 0.00 & 0.00 & 0.00 & 0.00 & 0.00 & 0.00 & 0.00 & 0.00 & 0.00 & 0.00 \\
\hline 1.06 & 2.07 & 0.95 & 0.89 & 0.89 & 0.89 & 0.77 & 0.41 & 0.71 & 0.41 & 0.77 \\
\hline 21.65 & 27.14 & 24.18 & 22.66 & 23.59 & 23.93 & 23.00 & 22.15 & 23.00 & 20.12 & 25.03 \\
\hline 30.31 & 30.38 & 23.87 & 25.99 & 25.71 & 24.58 & 27.64 & 29.74 & 26.11 & 24.68 & 24.03 \\
\hline 0.00 & 0.00 & 0.00 & 0.00 & 0.00 & 0.00 & 0.00 & 0.00 & 0.00 & 0.00 & 0.00 \\
\hline 12.05 & 8.67 & 11.53 & 11.69 & 11.59 & 11.76 & 13.17 & 13.51 & 12.03 & 11.27 & 11.35 \\
\hline 7.12 & 5.33 & 5.75 & 6.07 & 5.83 & 6.10 & 7.53 & 8.02 & 6.45 & 5.16 & 5.69 \\
\hline 4.31 & 2.83 & 5.53 & 5.29 & 5.50 & 5.32 & 5.05 & 4.79 & 5.18 & 6.02 & 5.41 \\
\hline 10.77 & 2.45 & 9.73 & 10.06 & 9.56 & 10.15 & 9.16 & 5.63 & 9.28 & 9.73 & 9.70 \\
\hline 6.52 & 1.30 & 9.37 & 8.77 & 9.03 & 8.85 & 6.13 & 3.36 & 7.45 & 11.34 & 9.23 \\
\hline 0.85 & 8.13 & 0.00 & 0.00 & 0.00 & 0.00 & 0.96 & 4.27 & 0.89 & 0.00 & 0.00 \\
\hline 0.57 & 4.76 & 0.00 & 0.00 & 0.00 & 0.00 & 0.71 & 2.82 & 0.79 & 0.00 & 0.00 \\
\hline 1.91 & 1.87 & 2.59 & 2.42 & 2.50 & 2.46 & 2.01 & 1.92 & 2.29 & 2.84 & 2.47 \\
\hline 2.59 & 3.62 & 4.41 & 3.88 & 4.05 & 4.17 & 2.84 & 2.34 & 3.27 & 3.54 & 3.75 \\
\hline 0.32 & 0.58 & 0.46 & 0.44 & 0.44 & 0.51 & 0.35 & 0.23 & 0.35 & 0.32 & 0.42 \\
\hline 100.02 & 99.13 & 95.48 & 99.09 & 99.30 & 99.14 & 99.32 & 99.18 & 97.78 & 98.91 & 99.47 \\
\hline
\end{tabular}

by from 20 to $30 \mathrm{ppm}$. Ni remains essentially unchanged. The $\mathrm{Nb}$ data, unfortunately, are somewhat suspect, because of sporadic contamination from the tungsten carbide shaker mill that was used to powder the samples. Samples which appear to have minimum $\mathrm{Nb}$ contamination, determined by comparison with relative enrichments in $\mathrm{Zr}$ and $\mathrm{K}_{2} \mathrm{O}$ in the glasses, are indicated in Table 4 by an asterisk (*). The contamination problem appears to be less severe than in samples powdered aboard the Glomar Challenger using a tungsten carbide shatterbox (Joron et al., this volume), having affected mainly the hardest, near-glassy, basalts.

The trace element data are used in conjunction with glass compositions to evaluate (1) magmatic processes affecting the Rise tholeiite suite, (2) chemical variations among fracture zone basalts, and (3) the alkali basalttholeiite mixing hypothesis of Johnson (1979) and Batiza and Johnson (this volume).

\section{MAGMATIC PROCESSES IN THE RISE THOLEIITE SUITE}

There are two types of chemical variation that occur among the glass groups. The first, from which we exclude glass Groups G and L (the seamount glasses), is the general trend of enrichment in iron and other elements produced by crystal fractionation, following the conclusions of Clague and Bunch (1976), Batiza et al. (1977), and Srivastava et al. (this volume). Iron enrichment is paralleled by enrichments in $\mathrm{TiO}_{2}, \mathrm{~K}_{2} \mathrm{O}$, and $\mathrm{P}_{2} \mathrm{O}_{5}$ as $\mathrm{MgO}$ decreases (Figure 2). There are less pronounced increases in $\mathrm{SiO}_{2}$ and $\mathrm{Na}_{2} \mathrm{O}$ as $\mathrm{MgO}$ decreases, and actual decreases in $\mathrm{CaO}$ and $\mathrm{Al}_{2} \mathrm{O}_{3}$ (Figure 3). The general trends of these variations are indicated by arrows labeled "Type 1" on Figures 2 and 3.

The second type of variation amounts to what might be termed the "band-width" of the data-point scatter on Figures 2 and 3, indicated schematically by doubleheaded arrows labeled "Type 2." The extreme variation of this type includes the seamount glass groups, G and L. However, even within the Rise tholeiite suite a range exists.

Fractionation (Type 1) can be considered by reference to possible combinations of fractionating minerals based on single-mineral control lines on Figures 2 and 3. If only a single mineral were involved in fractionation (say, olivine), then data points would tend to cluster along a single-mineral (i.e., olivine) control line (Wright, 1974). Since the overall trends on Figures 2 and 3 parallel no single control line, some combination of minerals must be involved.

Despite the complications introduced by "bandwidth" variations, there is still a clear tendency for the glass data to form not linear, but curved, trends (indicated schematically by the curvature of the Type 1 arrows). This curvature is especially evident when glass groups from the same dredge or drill sites are connected by solid lines, as on Figures 2 and 3 (e.g., Groups H, I, and $\mathrm{J}$ ). In general, this curvature can be ascribed to a decrease in the proportion of olivine, and an increase in clinopyroxene, as fractionation proceeds. Plagioclase changes proportionally by considerably less. This is in accord with observed changes in mineralogy. Olivine and spinel are the only phenocrysts in the most magnesian basalts, but plagioclase crystallizes with olivine in the groundmass. Iron-rich basalts, however, have only very rare, probably mestastable olivine in quench samples, but have abundant microphenocrystal plagioclase-clinopyroxene intergrowths (Thompson et al., this volume; Natland, crystal morphologies chapter, this volume). The effect of these changes in the fractionating mineral assemblage can be considered readily in terms of $\mathrm{CaO}$ and $\mathrm{Al}_{2} \mathrm{O}_{3}$ (Figure 3), as we shall now discuss. 


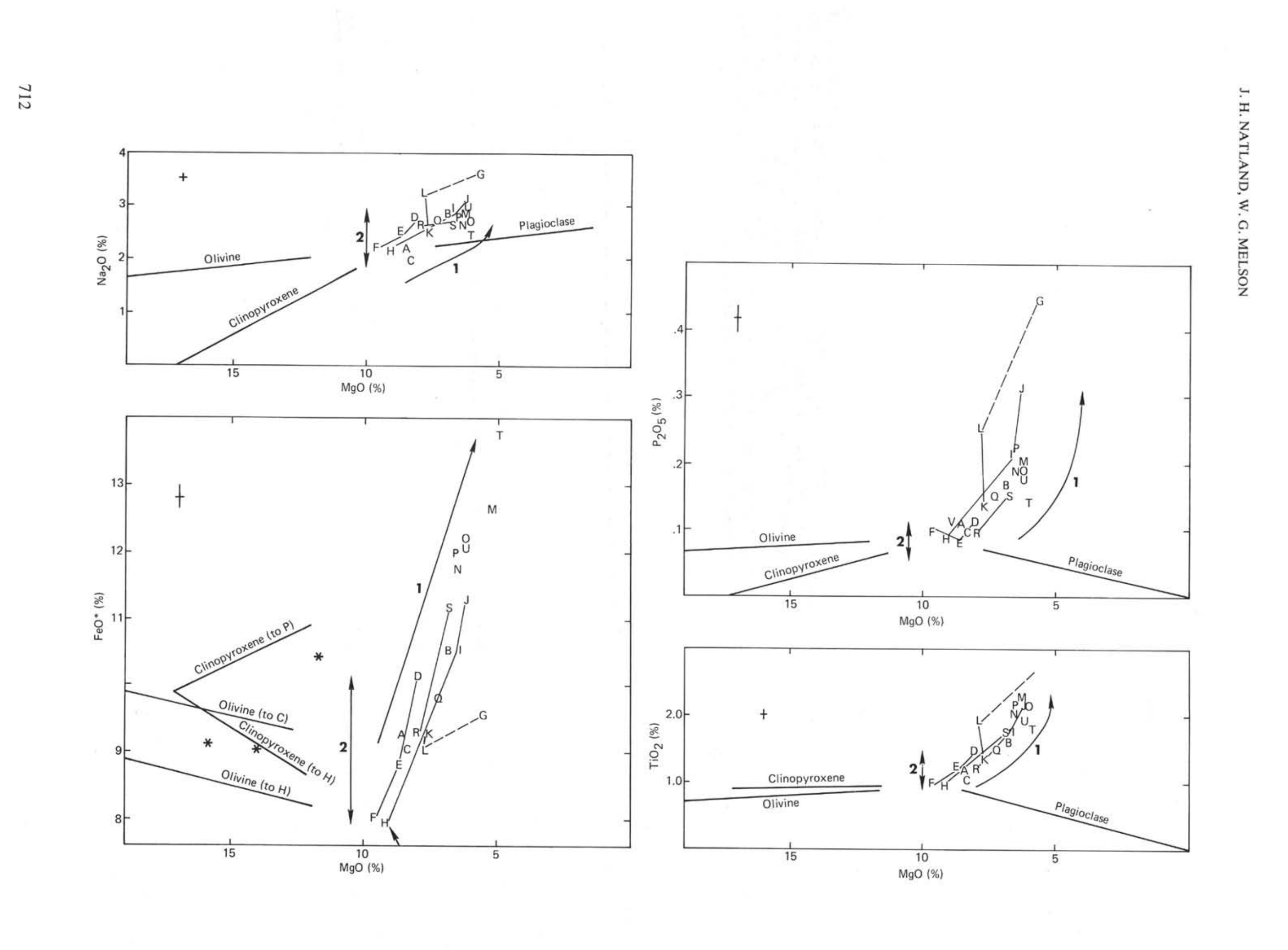



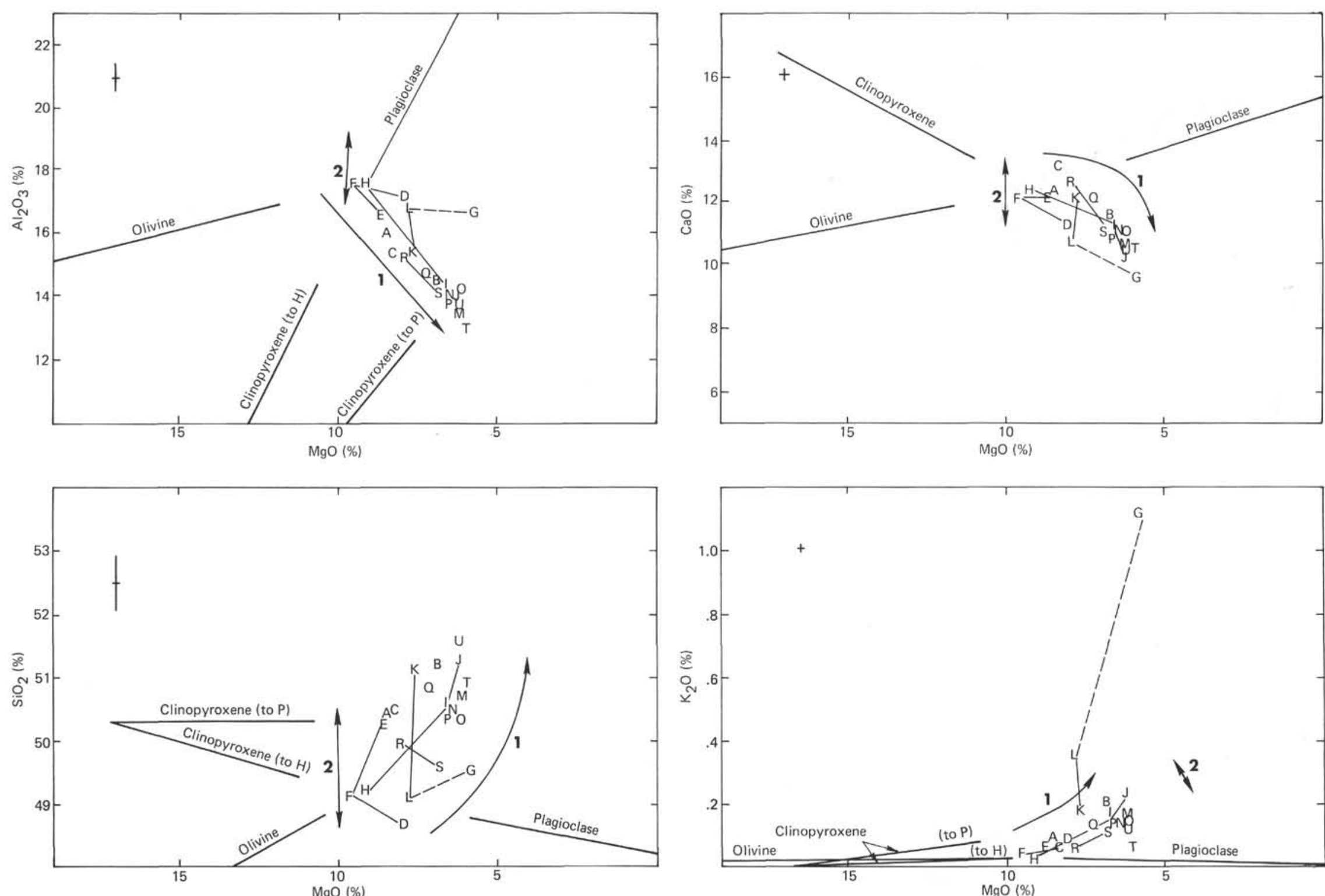

Figure 2. $\mathrm{MgO}$ variation diagrams for the glass groups in Table 3 are plotted by alphabetic designation. Solid lines link glass groups from the same dredge haul or drill site. "Transitional" and alkalic glass Groups $K$ and L are linked by a dashed line. Lines labeled with mineral names represent control lines from representative mineral analyses taken from Batiza et al. (1977). Arrows labeled 1 and 2 are schematic fractionation and "band-width" variations, respectively, discussed in the text. Asterisks represent whole-rock data on olivine-rich tholeiites from dredge SD-7 (Schrader et al., this volume). Error bars in upper left corners give twice standard deviation of glass analyses of Group U (dredge PL-2D) given in text. 


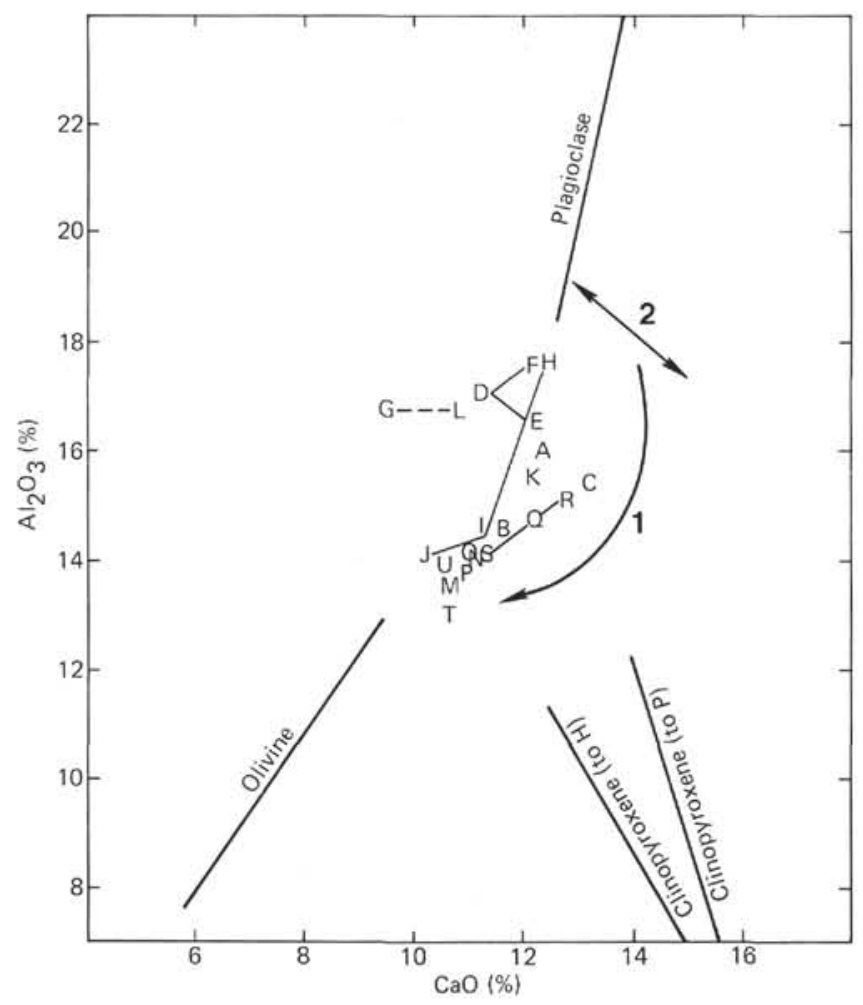

Figure 3. $\mathrm{CaO}$ versus $\mathrm{Al}_{2} \mathrm{O}_{3}$ for the glass groups listed in Table 3. Mineral control lines, plotting conventions, "band-width," and fractionation variations are as in Figure 2.

TABLE 4

Trace Element Data for Dredged Basalts

\begin{tabular}{lrcrccc}
\hline Sample & $\mathrm{Ni}$ & $\mathrm{Sr}$ & $\mathrm{Zr}$ & $\mathrm{Y}$ & $\mathrm{Nb}$ & $\mathrm{Rb}$ \\
\hline DS-3-3 & 218 & 106 & 31 & 21 & 14 & 2.0 \\
DS-3-6 & 58 & 140 & 203 & 69 & $8 *$ & 2.2 \\
DS-4-1 & 180 & 251 & 158 & 33 & 24 & 7.0 \\
DS-4-2 & 114 & 163 & 86 & 24 & 14 & 1.8 \\
DS-4-6 & 175 & 259 & 165 & 32 & $10^{*}$ & 7.2 \\
DS-4-7 & 111 & 159 & 90 & 24 & 8 & 1.0 \\
DS-4-14 & 173 & 259 & 159 & 36 & $13 *$ & 6.0 \\
DS-5-6 & 56 & 120 & 158 & 49 & $5 *$ & 3.2 \\
DS-5-7 & 62 & 156 & 163 & - & - & - \\
DS-5-12 & 61 & 153 & 162 & - & - & - \\
SD-8 & 115 & 354 & 189 & 40 & $32 *$ & 15 \\
\hline
\end{tabular}

${ }^{*}$ Least affected by tungsten carbide contamination.

The most plausible parental composition for the Rise tholeiite suite is glass Group $\mathrm{H}$, which has the highest $\mathrm{MgO}, \mathrm{Mg} /(\mathrm{Mg} \pm \mathrm{Fe})(0.71)$, and $\mathrm{CaO}$, but lowest $\mathrm{K}_{2} \mathrm{O}$, $\mathrm{TiO}_{2}, \mathrm{P}_{2} \mathrm{O}_{5}$, and $\mathrm{FeO}^{*}$ of all glasses sampled from the Rise crest or its flanks. The whole-rock equivalent of this glass group is substantially aphyric (Johnson, 1979), and has the highest $\mathrm{Ni}(218 \mathrm{ppm})$ but lowest $\mathrm{Zr}$ and rare-earth element abundances of the entire suite (Table 4; Batiza and Johnson, this volume). This basalt approximates in composition aphyric basalts or glasses considered to be possible direct partial melts of the mantle, and parental to the Mid-Atlantic Ridge tholeiite suite (Frey et al., 1974; Rhodes and Dungan, 1979;
TABLE 5

Correlation Coefficients, Standard Error (ppm), and Comparisons with Published Data for Leg 45 Standards

\begin{tabular}{|c|c|c|c|c|c|}
\hline & $r^{2}$ & $S_{y \cdot x}$ & \multicolumn{3}{|c|}{ No. Standards } \\
\hline $\mathrm{Ni}$ & 0.9977 & 2.9 & \multicolumn{3}{|c|}{11 (USGS. Fren } \\
\hline $\mathrm{Sr}$ & 0.9976 & 9.9 & \multicolumn{3}{|c|}{15 (USGS, French, Leg 45) } \\
\hline $\mathrm{Zr}$ & 0.9955 & 9.3 & \multicolumn{3}{|c|}{13 (USGS, French, Leg 45) } \\
\hline $\mathrm{Y}$ & 0.9854 & 1.9 & \multicolumn{3}{|c|}{$\begin{array}{l}7 \text { (USGS) } \\
10 \text { (USGS, French) }\end{array}$} \\
\hline $\mathrm{Nb}$ & 0.9920 & 1.4 & \multicolumn{3}{|c|}{10 (USGS, French) } \\
\hline $\mathrm{Rb}$ & 0.9999 & 2.0 & \multicolumn{3}{|c|}{14 (USGS, French) } \\
\hline \multirow{2}{*}{\multicolumn{2}{|c|}{$\begin{array}{l}\text { Hole-Core- } \\
\text { Section }\end{array}$}} & \multicolumn{2}{|r|}{$\mathrm{Ni}$} & \multicolumn{2}{|r|}{ Sr } \\
\hline & & $\mathrm{COB}$ & This Study & $\mathrm{COB}$ & This Study \\
\hline 395 & $15-3$ & 91 & 89 & 160 & 153 \\
\hline 395 & $-15-5$ & 95 & 90 & 158 & 157 \\
\hline 395 & -63-1 & 129 & - & 132 & 135 \\
\hline 395 & & 170 & 172 & 324 & 316 \\
\hline \multicolumn{2}{|c|}{$395-18-1$} & & - & 6 & 5 \\
\hline & & & $\mathrm{Zr}$ & & \\
\hline 395 & $15-3$ & 97 & 89 & \multirow{5}{*}{\multicolumn{2}{|c|}{$\begin{array}{l}\text { No } C O B \text { data for } Y \\
\text { Nb; no comparison } \\
\text { attempted for } \mathrm{Rb} \text {. }\end{array}$}} \\
\hline 395 & $15-5$ & 84 & 86 & & \\
\hline 395 & $63-1$ & 68 & 75 & & \\
\hline 395 & & 16 & 12 & & \\
\hline 395 & $8-1$ & 4 & 5 & & \\
\hline
\end{tabular}

${ }^{\mathrm{a}}$ Calibration does not include peridotites, etc.

Presnall et al., 1979). It is the most primitive East Pacific Rise basalt ever recovered from a Rise crest or flank location away from a fracture zone.

For this glass group to be related to glasses of the other, somewhat more fractionated olivine tholeiites (i.e., Groups A, K, Q, or R) by shallow fractionation, $\mathrm{A}_{2} \mathrm{O}_{3}$ must drop by about 2 per cent whereas $\mathrm{CaO}$ does not change at all (Figure 3 ). This could result by combining fractionation of plagioclase and olivine, but would be hindered by fractionating clinopyroxene at this stage, as is evident from the mineral control lines on Figure 3. Later, addition of clinopyroxene and removal of olivine from the fractionating mineral assemblage would skew the trend to the left on Figure 3. An identical argument can be made for several of the $\mathrm{MgO}$ variation diagrams on Figure 2.

An important question is whether the conditions of fractionation can vary so as to produce different trends, thus contributing to the "band width" on Figures 2 and 3 . For several of the FETI glasses, evidently fractionation processes have been virtually identical since they are so similar in composition. If anything, the "band width" substantially decreases as the compositions become more evolved (e.g., $\mathrm{FeO}^{*}, \mathrm{CaO}$, or $\mathrm{Al}_{2} \mathrm{O}_{3}$ versus $\mathrm{MgO}$ on Figure 2). This implies a remarkable consistency of fractionation processes over several million years for the East Pacific Rise, and at widely dispersed geographic locations on the modern Rise. This consistency is implicit in the glass group equivalences and near-equivalences cited earlier.

However, glass Groups I and J (recovered in the same dredge with "parental" glass Group H) clearly diverge from the general pattern of enrichment in certain ox- 
ides. Although Group $J$ has the highest $\mathrm{K}_{2} \mathrm{O}$ and $\mathrm{P}_{2} \mathrm{O}_{5}$ of all the East Pacific Rise tholeiites (Table 3), and its whole-rock equivalent has the highest $\mathrm{Zr}$ (Table 4), it has less $\mathrm{FeO}^{*}$ and $\mathrm{TiO}_{2}$ than a number of other FETI glasses. This can most readily be appreciated on Figure 4 , where $\mathrm{P}_{2} \mathrm{O}_{5}$ and $\mathrm{K}_{2} \mathrm{O}$ are plotted versus $\mathrm{TiO}_{2}$. Group I shows the same tendencies, but to a lesser degree.

The simplest explanation for this divergence is that conditions of fractionation favored precipitation of a small amount of titanomagnetite along with the major silicate phases, starting at a rather early stage of the fractionation sequence. Such fractionation could have been produced by higher oxygen fugacities (Osborn, $1959 ; 1962)$, and perhaps occurred at levels in the crust where oxygenating pore fluids permeated fractures more readily than usual.

Another possibility is that glass Groups I and $\mathrm{J}$ are derived from more alkalic (less depleted) parents, perhaps similar to Groups $G$ and $L$ from the seamounts. Trace element data appear to exclude this, however, since the whole-rock equivalent of Group $\mathrm{J}$ follows the
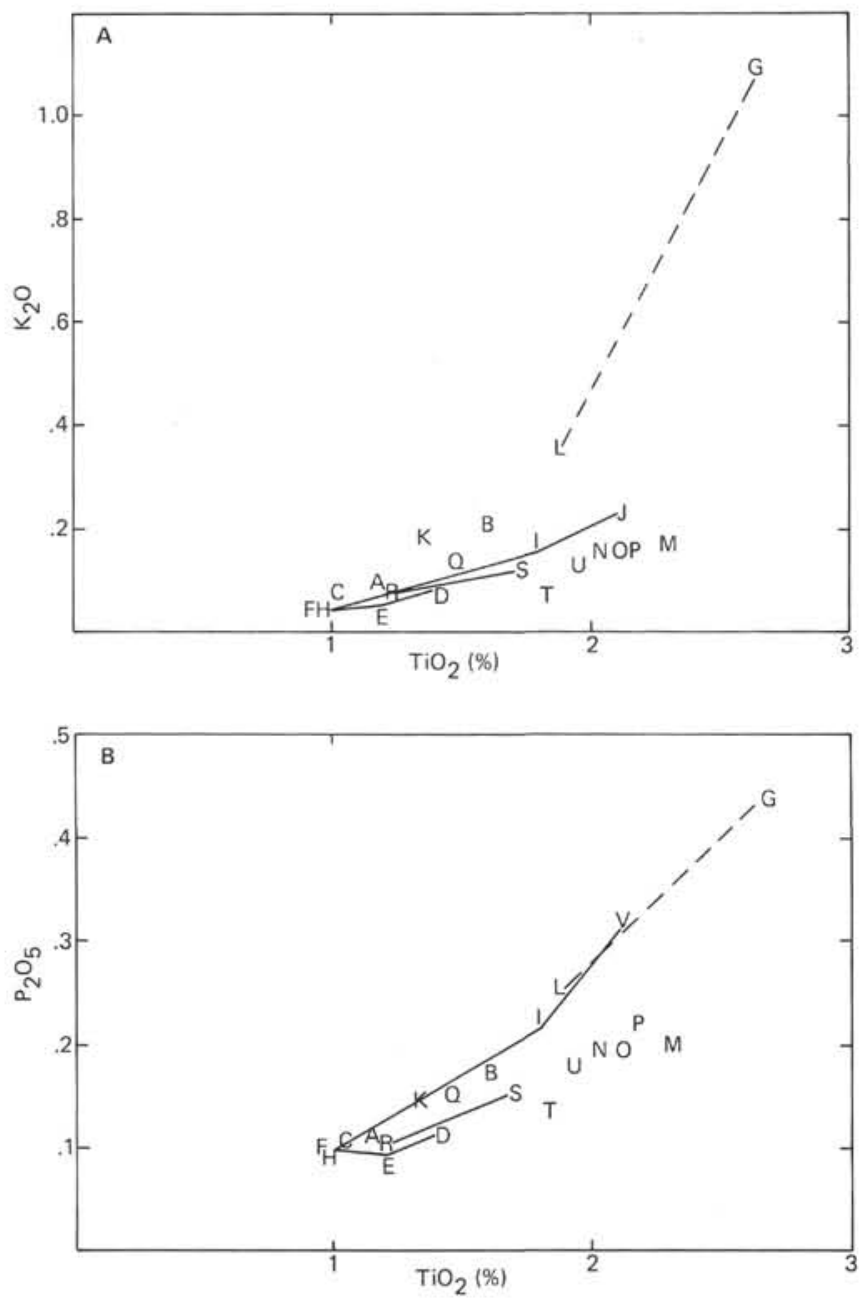

Figure 4. $\mathrm{TiO}_{2}$ versus ( $\left.\mathrm{A}\right) \mathrm{K}_{2} \mathrm{O}$ and ( $\mathrm{B}$ ) $\mathrm{P}_{2} \mathrm{O}_{5}$ for the glass groups listed in Table 3. Diagram conventions are as in Figure 2. same general trend of $\mathrm{Y}$ and $\mathrm{Zr}$ enrichment (Figure 5) as do the other drilled and dredged tholeiites. All the tholeiites are clearly distinct from the seamount basalts, which show considerably lower $\mathrm{Y}$ at high $\mathrm{Zr}$ levels.

A final possibility is that the fractionation occurred at somewhat elevated pressures, and involved different proportions of the only major $\mathrm{TiO}_{2}$-bearing silicate, clinopyroxene. However, this probably would have enriched $\mathrm{Al}_{2} \mathrm{O}_{3}$ in residual liquids more than is evident on the $\mathrm{Al}_{2} \mathrm{O}_{3}$ variation diagram of Figure 2 . Therefore, titanomagnetite fractionation probably accounts for the comparatively low $\mathrm{TiO}_{2}$ and $\mathrm{FeO}^{*}$ in these fractionated samples.

We turn now to other explanations for the origin of the "band width" (Type 2) variations on Figures 2 and 3 . The data point scatter among the tholeiites cannot entirely be ascribed to analytical uncertainty, because there is some structure to the plots which recurs on several diagrams. Notably there is consistency of behavior where the oxide of a low partition-coefficient element $\left(\mathrm{K}_{2} \mathrm{O}, \mathrm{P}_{2} \mathrm{O}_{5}, \mathrm{Na}_{2} \mathrm{O}\right.$, and $\left.\mathrm{TiO}_{2}\right)$ is plotted versus $\mathrm{MgO}$. The structure is revealed by the lines linking glass groups from the same dredge or DSDP sites. At the extreme of high $\mathrm{K}_{2} \mathrm{O}, \mathrm{P}_{2} \mathrm{O}_{5}, \mathrm{Na}_{2} \mathrm{O}$, and $\mathrm{TiO}_{2}$ abundances are Groups $\mathrm{G}$ and $\mathrm{L}$ (linked by a dashed line, since they are not at the same location), the seamount transitional and alkalic basalts glasses. At the other extreme is Group T, from the Galapagos Rift (Site 424) which always plots below the last magnesian East Pacific Rise glasses on these four diagrams. Within the East Pacific Rise tholeiites, the lines linking Groups $\mathrm{R}$ and $\mathrm{S}$ (Site 429) plot parallel to, but below, lines linking Groups D and $\mathrm{E}$ (dredge SD-7) and $\mathrm{H}$ and I (dredge SD-3).

In effect, these variations amount to there being a range of parental compositions upon which fractionation is superimposed. There are several ways to produce a range of parental compositions:

1) Vary the degree of melting of a homogeneous source in the mantle.

2) Vary the depth of melting in the mantle and/or allow fractionation to occur at both high and low pressures. Either case would involve different proportions of minerals, different mineral compositions, and perhaps different minerals altogether.

3) Vary the composition of the source.

4) Mix primitive magmas with evolved magmas (ferrobasalts) at high levels in the crust.

Alternative 1 appears to explain the difference between Group T from the Galapagos Rift and the East Pacific Rise tholeiitic glasses. All basalts from the Galapagos Rift (including those from Site 425, for which we have no glasses), have systematically lower $\mathrm{TiO}_{2}$, $\mathrm{K}_{2} \mathrm{O}, \mathrm{P}_{2} \mathrm{O}_{5}, \mathrm{Sr}, \mathrm{Zr}$, and rare-earth element abundances than East Pacific Rise basalts (Srivastava et al., this volume; Joron et al., this volume). However, when elements with very low partition coefficients (the so-called hygromagmatophile elements) are compared, the same ratios are observed, implying that the mantle sources of the two regions are about comparably depleted (Joron et al., this volume). Although no truly primitive Galap- 


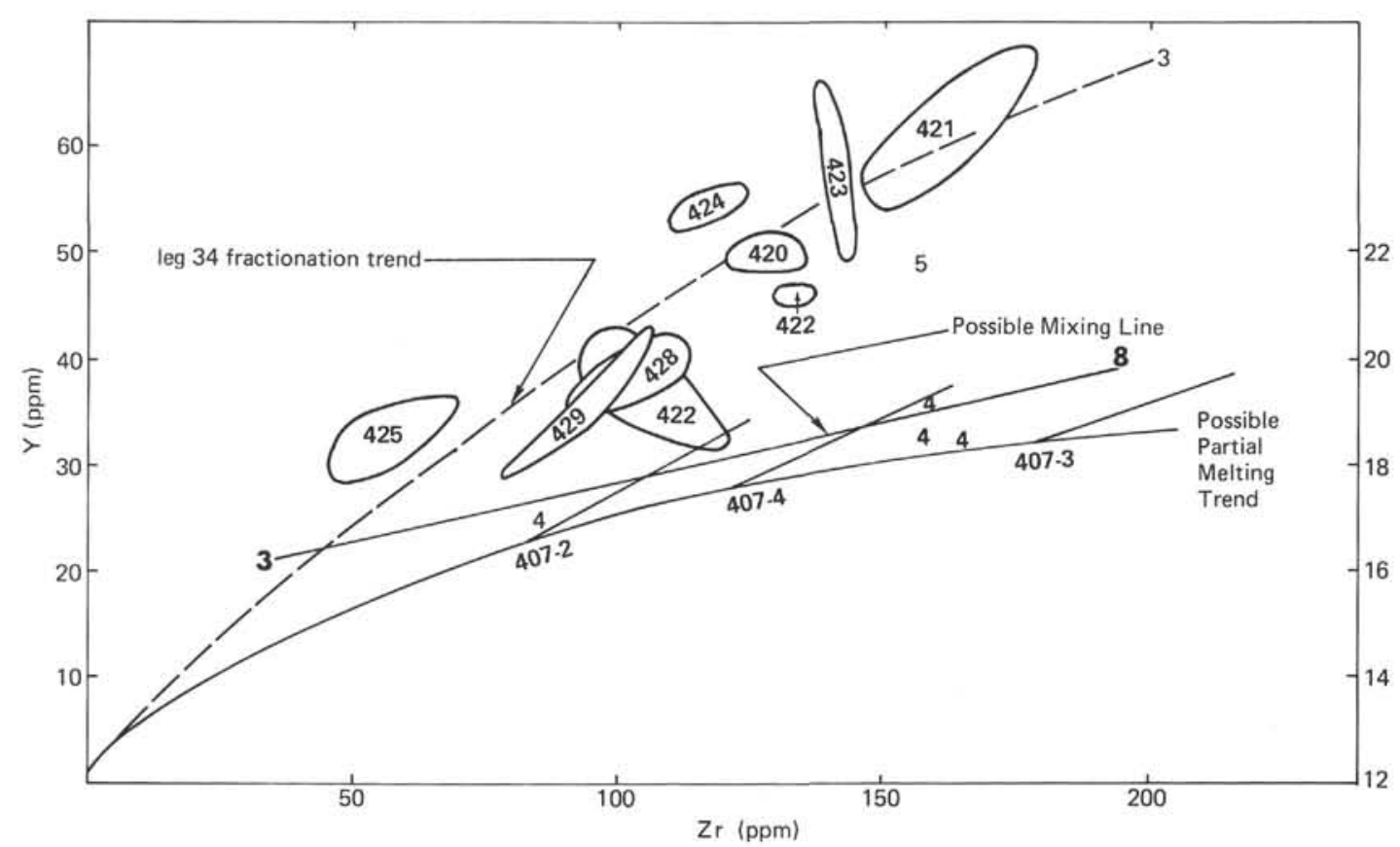

Figure 5. Zr versus $Y$. Data from Table 4 are indicated by the number of the dredge station (i.e., $3=D S$ $-3 ; 8=S D-8$, etc.; see Table 1). Data fields are for Leg 54 samples from Sites 420, 421, 422, 423, 428, and 429 (East Pacific Rise) and 424 and 425 (Galapagos Rift) from Joron et al. (this volume). Possible partial melting and fractionation trends from Tarney et al. (1979). Short fractionation lines labeled 407-2, 407-3, and 407-4 correspond to trends for three chemical groups from Site 407 in the North Atlantic. The mixing line is based on a suggestion by Batiza and Johnson (this volume) that dredge DS-4 "transitional"' (bold 4's) basalts are 50:50 mixes of dredge DS-3-3 (bold 3) and SD-8 (bold 8) end members. Based on $Y$ and $\mathrm{Zr}$, the proportion would be about 20:80.

agos Rift basalts have been recovered, extrapolating trace element abundances to primitive compositions (say with $\mathrm{MgO}=9.0 \%$ ) suggests that they would represent perhaps 50 per cent greater partial melting than the most primitive East Pacific Rise "parental" compositions (in which low-partition-coefficient elements would be about twice as abundant, assuming $\mathrm{K}_{\mathrm{D}} \sim \mathrm{O}$ ).

Alternative 2 (pressure effects) will be discussed in terms of fracture zone basalts in a later section.

Alternative 3 (heterogeneous source compositions) must be invoked to explain the seamount glasses (Groups G and L), as discussed earlier here and elsewhere by Batiza and Johnson (this volume). It may also partly explain some Siqueiros fracture zone tholeiites, as we shall shortly discuss, although we lack the critical data to evaluate this.

Alternative 4 (magma mixing) might be particularly important for explaining differences in $\mathrm{K}_{2} \mathrm{O}, \mathrm{P}_{2} \mathrm{O}_{5}$, $\mathrm{TiO}_{2}$, or any other low-partition-coefficient element among Rise tholeiites when compared at the same values of $\mathrm{MgO}$. This is shown schematically on Figure 6. Hybridization of a primitive olivine tholeiite such as glass Group $\mathrm{H}$ with a ferrobasalt would produce a spectrum of compositions along a mixing line such as that shown on the Figure. Much of this spectrum would still tend to fractionate plagioclase and olivine, based on our earlier discussion, producing the secondary, sub-parallel trends shown on Figure 6. One of these could be analogous to the trends linking Groups R and S (Site 429) on plots of $\mathrm{MgO}$ versus $\mathrm{TiO}_{2}, \mathrm{~K}_{2} \mathrm{O}$, and $\mathrm{P}_{2} \mathrm{O}_{5}$ on Figure 2 .
Truthfully, it is difficult to prove whether small source heterogeneities, variations in the degree of melting or of high-pressure fractionation, or the type of mixing just described, are responsible for the small variations among the more magnesian Rise tholeiites (fracture zone olivine tholeiites are to be considered later). Quantitative modeling of these alternatives would not be conclusive, nor would it necessarily be successful, given the small excesses of chemical differences among glass groups over the analytical uncertainty. The implication that mixing could be important, especially in a region with a postulated steady-state axial magma reservoir (e.g., Rosendahl, 1976), indicates that our choice of parental composition (glass Group H) is appropriate. It could ultimately be related to all other Rise tholeiites by a combination of fractionation and mixing.

Clague and Bunch (1976) used the phosphorus fractionation index of Anderson and Greenland (1969) to check their computations of total fractionation based on major oxides. The method can be extended to any other low-partition-coefficient element provided its abundance is known in both inferred parent and daughter compositions (e.g., Arth, 1976). Calculated ranges of bulk fractionation for representative intermediate and fractionated compositions based on several such elements or oxides are presented in Table 6 . Although the proportions differ somewhat depending on the element or oxide selected a general range of 50 to 75 per cent fractionation is required to produce FETI compositions from glass Group H. 


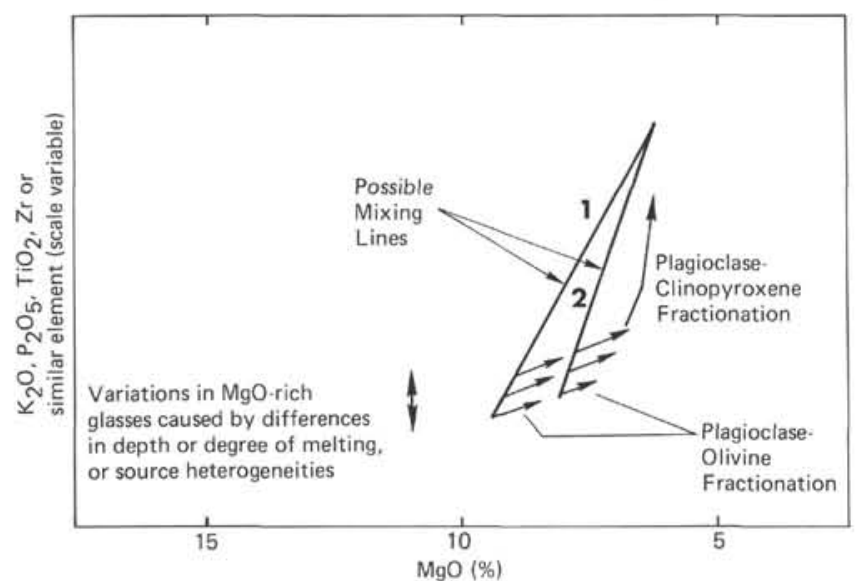

Figure 6. Possible relationships between fractionation and mixing for a low-partition-coefficient minor oxide or trace element. A primitive olivine tholeiite similar to Sample DS-3-3 (glass Group H) supplied to the base of an axial magma chamber at the East Pacific Rise could mix with ferrobasalt, providing a spectrum of different parental compositions which would separately fractionate plagioclase and olivine along the arrowed trend lines. Later clinopyroxene joins and olivine leaves the fractionating mineral assemblage, and the fractionation trends steepen. Based on criteria discussed in Natland (Axial Magma Chambers chapter, this volume), mixing trend 1 appears to be unlikely for glasses with $\mathrm{MgO}>8$ per cent, hence scatter at high $\mathrm{MgO}$ is probably the result of source variations indicated on the figure ("band-width" double-headed arrow).

TABLE 6

Percentage Fractionation Calculated from $\mathrm{K}_{2} \mathrm{O}, \mathrm{P}_{2} \mathrm{O}_{5}$, and $\mathrm{Zr}$

\begin{tabular}{|c|c|c|c|c|}
\hline \multicolumn{5}{|c|}{ Parent DS-3-3 (glass Group H) to the following samples: } \\
\hline Sample & DS-4-2 & DS-5-7 & DS-3-6 & Site 423 \\
\hline Glass Group & $\mathrm{K}$ & M & J & $\mathrm{P}$ \\
\hline \multicolumn{5}{|c|}{ Calculation Basis ${ }^{\mathrm{a}}$ : } \\
\hline $\mathrm{K}_{2} \mathrm{O}^{\mathrm{b}}$ & 71 & 75 & 83 & 73 \\
\hline $\mathrm{P}_{2} \mathrm{O}_{5}{ }^{\mathrm{b}}$ & 50 & 55 & 71 & 61 \\
\hline $\mathrm{Zrc}^{2}$ & 64 & 81 & 85 & 78 \\
\hline
\end{tabular}

${ }^{\mathrm{a}}$ For bulk partition coefficient $K_{D} \approx 0,\left[\left(C_{L}-C_{P}\right) / C_{P}\right] \times$ $100=\%$ fractionation, where $C_{L}=$ concentration of element or oxide in residual liquid and $C_{P}=i$ its concentration in the parent (Anderson and Greenland, 1969; Arth, 1976). ${ }^{b}$ Glass Group data (Table 3).

${ }^{c}$ Data from Table 4, except Site 423, which is average of $\mathrm{Zr}$ for three samples listed in Joron et al. (this volume).

\section{CHEMICAL VARIATIONS AMONG SIQUEIROS FRACTURE ZONE BASALTS}

When the "band-width" (Type 2) variations among olivine-bearing tholeiites are large, we can be reasonably certain that processes other than fractionation and mixing are responsible. This is the case among Siqueiros fracture zone olivine tholeiites, represented by glass Groups A, C, D, E, and F. The latter three are from the same dredge haul (SD-7) and Group C is from dredge SD-6, whose trace crossed that of SD-7 (Figure 1). Group A is from dredge SD-3 some $15 \mathrm{~km}$ to the west. All are from within the transform fault, some 300-1000 meters deeper than the nearby crest of the East Pacific Rise. With one exception (glass Group $\mathrm{H}$ ), the five groups are the most magnesian of all the glasses recovered from the region. On Figure 2, the "band-width" is indicated by arrows drawn at fixed $\mathrm{MgO}$, to show that these chemical differences are best compared at the same $\mathrm{MgO}$ (e.g., glass Groups C and D). The "band-width" is thus not orthogonal to the fractionation (Type 1) trends, and in some cases (i.e., $\mathrm{FeO}^{*}$ ) actually parallels it closely.

Within themselves, these five glass groups (A, C, D, $\mathrm{E}$, and F) encompass the entire "band-width" (Type 2) variation in $\mathrm{CaO}$ and $\mathrm{Al}_{2} \mathrm{O}_{3}$ (Fig. 3). Olivine and chromian spinel are the only phenocrysts in the basalts of dredge SD-7 (represented by Groups D, E, and F), which include two distinct petrographic types (Natland, Crystal Morphologies chapter, this volume). Basalts from dredge SD-3 are porphyritic, with coarse plagioclase megacrysts, some girdled by smaller olivine. Basalts from dredge SD-6 are sparsely microphyric, having small plagioclase and rare olivine microphenocrysts. These porphyritic rocks contrast markedly with the substantially aphyric olivine tholeiitic basalts and ferrobasalts of the Rise crest and its flanks (see East Pacific Rise Site Report, this volume).

One might expect some of these glass groups, especially from dredge SD-7, to be related by olivine fractionation. However, the glass groups trend almost directly orthogonal to an olivine control line on Figure 3, and even on the plot of $\mathrm{MgO}$ versus $\mathrm{FeO}^{*}$ on Figure 2. On that diagram, porphyritic whole-rock data from Schrader et al. (this volume) are plotted as asterisks, and these correspond closely to olivine-controlled trends leading to Groups E and F, respectively.

Glass Group D also has a considerably lower ratio of $\mathrm{CaO} / \mathrm{Al}_{2} \mathrm{O}_{3}$ than Groups $\mathrm{E}$ and $\mathrm{F}$ and has the highest $\mathrm{K}_{2} \mathrm{O}, \mathrm{P}_{2} \mathrm{O}_{5}$, and $\mathrm{TiO}_{2}$ of the three. If Groups D and $\mathrm{E}$ are related to $\mathrm{F}$ by crystal fractionation, it must be by two completely different trends, both involving plagioclase and clinopyroxene, but more clinopyroxene in the case of Group D. Since only olivine and minor spinel are on the liquidus of all these basalts, evidently shallow fractionation was not involved at all. Although mixing of a Group F-type parent with ferrobasalt might have produced Group E, both glass Groups D and C lie off potential mixing trends on Figure 3. We conclude that the spectrum of olivine basalt glass group compositions is the result of high-pressure processes-variations in the depth or degree of melting, possible high-pressure fractionation, or source heterogeneities. In the case of glass Group D-with its elevated $\mathrm{K}_{2} \mathrm{O}, \mathrm{P}_{2} \mathrm{O}$, and $\mathrm{TiO}_{2}$ it approaches the composition of "transitional" glass Group L, which it matches in other oxides as well (Figure 2). A source heterogeneity may well have been involved. In the Siqueiros fracture zone, we are thus seeing the imprint of a spectrum of processes which supply distinct compositional batches of magma to the sea floor. The types of variation (and, indeed, the preponderance 
of olivine tholeiite compositions) are reminiscent of the Mid-Atlantic Ridge (e.g., Blanchard et al., 1976; Bougault et al., 1978; Rhodes et al., 1978; Natland, 1978).

This range of compositions seems too great to produce the eventual very narrow range of FETI compositions that characterizes the Rise crest and flanks. Given such a range in potential starting compositions, one might expect them to be amplified by variable fractionation processes. Instead, either the range of parental compositions is more restricted beneath the Rise crest than the fracture zone, or efficient processes of mixing occur in the large, interconnected sub-axial magma chamber thought to underlie the Rise crest (e.g., Orcutt et al., 1975, 1976; Rosendahl, 1976). This mixing would ensure that a uniform parental composition is produced. The influence of postulated axial magma chambers on basalt compositions is discussed further in Natland (Axial Magma Chambers chapter, this volume).

Experimental studies suggest that the type of variations that exist among the fracture zone glasses could be caused by high-pressure fractionation processes. Without direct experimental data on these glasses, one cannot be sure precisely what phases were involved, or what depths. Phase relations in an aphyric olivine tholeiite from the Mid-Atlantic Ridge near $23^{\circ} \mathrm{N}$ (DSDP Site $395)$, which has lower $\mathrm{Mg} /(\mathrm{Mg}+\mathrm{Fe})(0.61)$ than the glass groups here $[\mathrm{Mg} /(\mathrm{Mg}+\mathrm{Fe})=0.66-0.70]$, and is therefore more evolved (Fujii et al., 1978), indicate that the temperature interval between crystallization of the major silicate phases (olivine, plagioclase, and clinopyroxene, in that order) decreases from over $70^{\circ}$ to less than $10^{\circ}$ between 1 atmosphere and 9 kbars. Above 9 kbars, olivine is no longer stable and clinopyroxene is the first phase to crystallize. Similarly, experiments on a magnesian glass $[\mathrm{Mg} /(\mathrm{Mg}+\mathrm{Fe})=0.68]$ from the FAMOUS area $\left(37^{\circ} \mathrm{N}\right)$ of the Mid-Atlantic Ridge (Bender et al., 1978) show a similar convergence of univariant curves with increasing pressure, until at about 10 kbars the crystallization interval is also less than $10^{\circ}$. In this more magnesian composition, however, plagioclase is not stable above $8 \mathrm{kbars}$, and orthopyroxene rather than plagioclase follows clinopyroxene crystallization above 10 kbars.

Evidently, then, fractionation at depths corresponding to 8-10 kbars among the more magnesian East Pacific Rise compositions could involve plagioclase and clinopyroxene in addition to olivine. At higher pressures, clinopyroxene or orthopyroxene could fractionate without either plagioclase or olivine. To Fujii et al. (1978), however, the significance of the narrowing of the crystallization interval in the Site 395 basalts which they investigated is that it could have melted in equilibrium with plagioclase lherzolite at $\sim 9$ kbars. Similar reasoning would suggest that the FAMOUS glass was produced by partial melting of a plagioclase-free lherzolite at somewhat higher pressures. In either case, fractionation per se would then only have occurred at these or lower pressures. For clinopyroxene or orthopyroxene to have influenced the glass compositions, particularly without the additional influence of plagioclase, it would have been during melting, rather than the shallower frac- tionation of the magmas. The variations in $\mathrm{CaO}$ evident on Figure 3 among glass Groups A, C, D, E, and F from the Siqueiros fracture zone can therefore be viewed as possibly expressing retention of clinopyroxene during melting. Increasing the degree of melting adds proportionally more clinopyroxene to the melt assemblage, increasing $\mathrm{CaO}$ and decreasing $\mathrm{Al}_{2} \mathrm{O}_{3}$ (Figure 3 ) and $\mathrm{FeO}^{*}$ (Figure 2). The seamount more-alkalic lavas (Groups G and L) represent smaller partial melts, consistent in part with their significantly more elevated abundances of $\mathrm{K}_{2} \mathrm{O}, \mathrm{P}_{2} \mathrm{O}_{5}$, and other low-partition-coefficient elements. Glass Group D is a somewhat greater partial melt, and glass Group C represents the greatest partial melt. Significantly, glass Group T from the Galapagos Rift, which we have earlier indicated stemmed from a parent that was a greater partial melt of the mantle than East Pacific Rise parental compositions, has lower $\mathrm{Al}_{2} \mathrm{O}_{3}$ than other East Pacific Rise FETI glasses. This feature requires that its parent had higher $\mathrm{CaO} / \mathrm{Al}_{2} \mathrm{O}_{3}$ (i.e., higher $\mathrm{CaO}$ ) than East Pacific Rise magnesian glasses, a consequence of a higher proportion of clinopyroxene added to the melt. We cannot tell what the parental $\mathrm{FeO}^{*}$ was.

The story is undoubtedly more complicated than this. The effects of high-pressure solid solution and the influence of other phases are difficult to assess. Undoubtedly, fractionation of olivine has occurred near the sea floor so that the glass compositions can no longer be the same as those produced by melting. Clinopyroxene was only one phase in an assemblage of minerals involved in melting. Its influence on compositions may be more readily detected by the graphical techniques employed here than other minerals. It is noteworthy, however, that clinopyroxene was also suggested to be a mantle residual phase controlling the compositions of primitive lavas drilled on Leg 37 in the FAMOUS area (Byerly and Wright, 1978).

\section{A MODEL FOR THE DIVERSITY OF FRACTURE ZONE BASALT COMPOSITIONS}

Presnall et al. (1979) have recently proposed a mechanism for producing uniform olivine tholeiite (parental) compositions along ridge-crest segments that can be used to discuss both the uniformity of East Pacific Rise crest compositions and the diversity of fracture zone basalts. Their mechanism is based on the experimental verification that there is a depression, or cusp, in the solidus curve in the system $\mathrm{CaO}-\mathrm{MgO}-\mathrm{Al}_{2} \mathrm{O}_{3}-\mathrm{SiO}_{2}$, at 9 kbars, where the transition from simplified plagioclase lherzolite to spinel lherzolite intersects the solidus and forms an invariant point. These authors also argue that the narrowing of the melting interval of experimentally investigated sea-floor basalts (e.g., Fujii et al., 1978; Bender et al., 1978) is a manifestation of melting at an analogous cusp in the mantle. They suggest that melting at this near-invariant point beneath ridge crests buffers the geothermal gradient such that melting stabilizes at about $30 \mathrm{~km}$ depth ( $9 \mathrm{kbars})$ to produce basalts of very uniform composition along the ridge crest. This is because equilibrium partial fusion at an invariant point will produce liquids of uniform composition through wide ranges in the extent of melting despite the propor- 
tion of phases present, until a residual phase is exhausted (Presnall, 1969). Only low-partition-coefficient trace and minor elements would show the effects of variable partial melting, simply a consequence of dilution.

Presnall et al. (1979) argue that different compositions would arise where the geothermal gradient is not buffered. The example they offer is that of melting accompanying the initial stages of rifting, where the geothermal gradient would intersect the solidus above 9 kbars before shifting to the cusp. In this sequence, alkalic olivine basalts would initially erupt, followed by abyssal olivine tholeiites. Presnall et al. (1979) point to the Afar as an example of such a petrologic transition at the initial stages of rifting (Gass, 1970, 1972; Mohr, 1971). Others would be the Eocene lavas and dike swarms of the Scottish Hebridges (Thompson et al., 1972), Ireland (Gamble, 1979), and East Greenland (Nielsen, 1978).

We can now readily adapt this model to the variety of rocks in the Siqueiros fracture zone region of the East Pacific Rise. The suite of very uniform fractionated FETI glasses which erupted well away from seamounts and the Siqueiros fracture zone could reflect a very uniform and persistent melting regime, such as stabilization of melting at a fixed depth with uniform geothermal gradient. A uniform parent would be supplied to the axial magma chamber, and uniform fractionation processes implicit in the existence of this steady-state feature would produce uniform trends of iron enrichment (with only occasional exceptions, such as glass Groups I and $\mathrm{J}$ ).

There are two situations, however, where such stability could not be achieved or sustained. These are offridge (seamount) volcanism, and fracture-zone volcanism.

Melting at 30-km depth beneath ridge crests, as advocated by Presnall et al. (1979), should produce a depleted refractory zone of mantle between $30 \mathrm{~km}$ and the Moho. The lithosphere is also known to cool and consequently thicken, probably by a sub-solidus underplating process, as it ages (Sclater et al., 1971). The geothermal gradient is effectively suppressed, except for perturbations which produce seamount volcanism. These perturbations would impinge at the base of the lithosphere at pressures greater than 9 kbars. The geothermal gradient beneath seamounts could never stabilize at a thermal cusp either because the lithosphere is too thick, because the phenomenon is not sufficiently long-lived, or because the plate is moving over the thermal perturbation (the plume hypothesis). In the system $\mathrm{CaO}-\mathrm{MgO}-\mathrm{Al}_{2} \mathrm{O}_{3}-\mathrm{SiO}_{2}$ above 9 kbars, there is a shift in the compositions of liquids along the solidus curve away from normative anorthite and diopside toward forsterite (Presnall et al., 1979) - that is, toward lower $\mathrm{CaO} / \mathrm{Al}_{2} \mathrm{O}_{3}$. A similar shift was evident in the earlier experimental results of Kushiro (1968). This chemical difference is the same as that already documented to exist between the seamount alkalic basalt suite and the Rise tholeiite suite, and within the group of five Siqueiros fracture zone olivine tholeiite glasses.

The transform fault is also a place where it would be difficult to stabilize melting at a thermal cusp. Since trans- form faults are those portions of fracture zones between volcanically active portions of Rise crests, they juxtapose very thin and hot lithosphere on one side, and thicker, colder lithosphere on the other, in an environment of shear. No permanently stable thermal regime seems likely, and both a range in primitive tholeiite compositions (glass Groups A, C, D, E, and F) and isolated alkalic basalts (glass Group G, dredge SD-8) might be expected.

Earlier, we suggested that magma mixing in an interconnected axial magma chamber could produce uniform parental compositions, leading to the uniform end products of East Pacific Rise fractionation. While this may well occur, the geochemical consequences of it cannot be distinguished from the alternative mechanism proposed here. Intuitively, it makes sense that conditions for melting beneath fracture zones are more variable than beneath segments of the East Pacific Rise, and this should be reflected in the basalt compositions.

\section{THOLEIITE-ALKALIC BASALT MIXING HYPOTHESIS}

Johnson (1979) and Batiza and Johnson (this volume) advocated an origin for "transitional" basalts from dredge DS-4 (glass Group L) by mixing between primitive (MgO-rich) tholeiite and alkalic basalt compositions. The new measurements of $\mathrm{Ni}$ and $\mathrm{Zr}$ show that the "transitional"' basalts do not lie on a mixing line between dredge SD-8 alkalic basalts and any known representative of the Rise tholeiite suite (Figure 7). They could lie on a mixing line between the SD- 8 basalt and the least fractionated Rise tholeiites in terms of $\mathrm{Y}$ versus $\mathrm{Zr}$ (Figure 5), but the proportions of the mix would be dominated by alkalic basalt (Batiza and Johnson, this volume, advocate a 50:50 mix). This is also suggested for the glasses (Groups $\mathrm{K}$ and $\mathrm{F}$ ) on the plot of $\mathrm{CaO}$ versus $\mathrm{Al}_{2} \mathrm{O}_{3}$ (Figure 3). Although we cannot preclude a hybrid origin between some tholeiite and some alkalic basalt, clearly, mixing between counterparts of analyzed compositions must be excluded.

In the meantime, with respect to the origin of the seamount suite, we prefer the interpretation that, along this portion of the East Pacific Rise, there are localized pockets of less depleted mantle whose solidus curve may be suppressed by their additional volatile and low-melting constituents, such as $\mathrm{Ti}_{2}, \mathrm{P}_{2} \mathrm{O}_{5}$, and $\mathrm{CO}_{2}$ (e.g., $\mathrm{Ku}$ shiro, 1975; Presnall et al., 1979), and which would therefore begin to melt at higher pressures in an area of uniform geothermal gradient. The combined effect of pressure and source heterogeneity would explain features such as the reduced $\mathrm{CaO} / \mathrm{Al}_{2} \mathrm{O}_{3}$ and $\mathrm{SiO}$, elevated $\mathrm{Zr}, \mathrm{TiO}_{2}, \mathrm{Sr}, \mathrm{Nb} / \mathrm{Zr}$, and $\mathrm{Ce} / \mathrm{Y}$ (Figure 8 ) and -reduced $\mathrm{Y} / \mathrm{Zr}$ (Figure 5) of these basalts. We see the East Pacific Rise as having a regional mantle source at one end of the spectrum of Rise-ridge mantle sources; it has a low proportion of such undepleted "pockets." At the other end of the spectrum is the North Atlantic, which seems to have a mantle source which consists of little else but such undepleted pockets (e.g., Wood et al., 1979; Bougault et al., 1979; Tarney et al., 1979) with many compositions (Cann et al., 1979). An explanation for the sequence seen on OCP Ridge-where undeniably depleted 


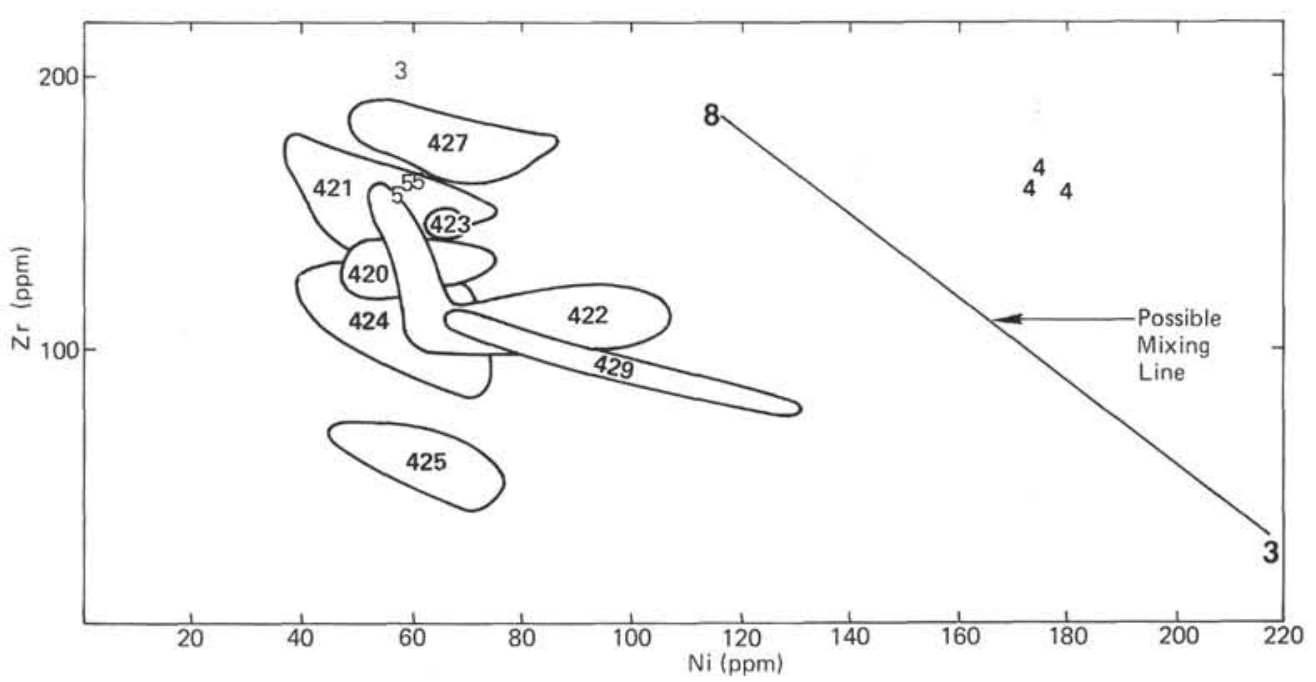

Figure 7. Ni versus Zr. Labeling conventions, mixing line, as in Figure 5. DS-4 "transitional"' samples do not fall on the mixing line.

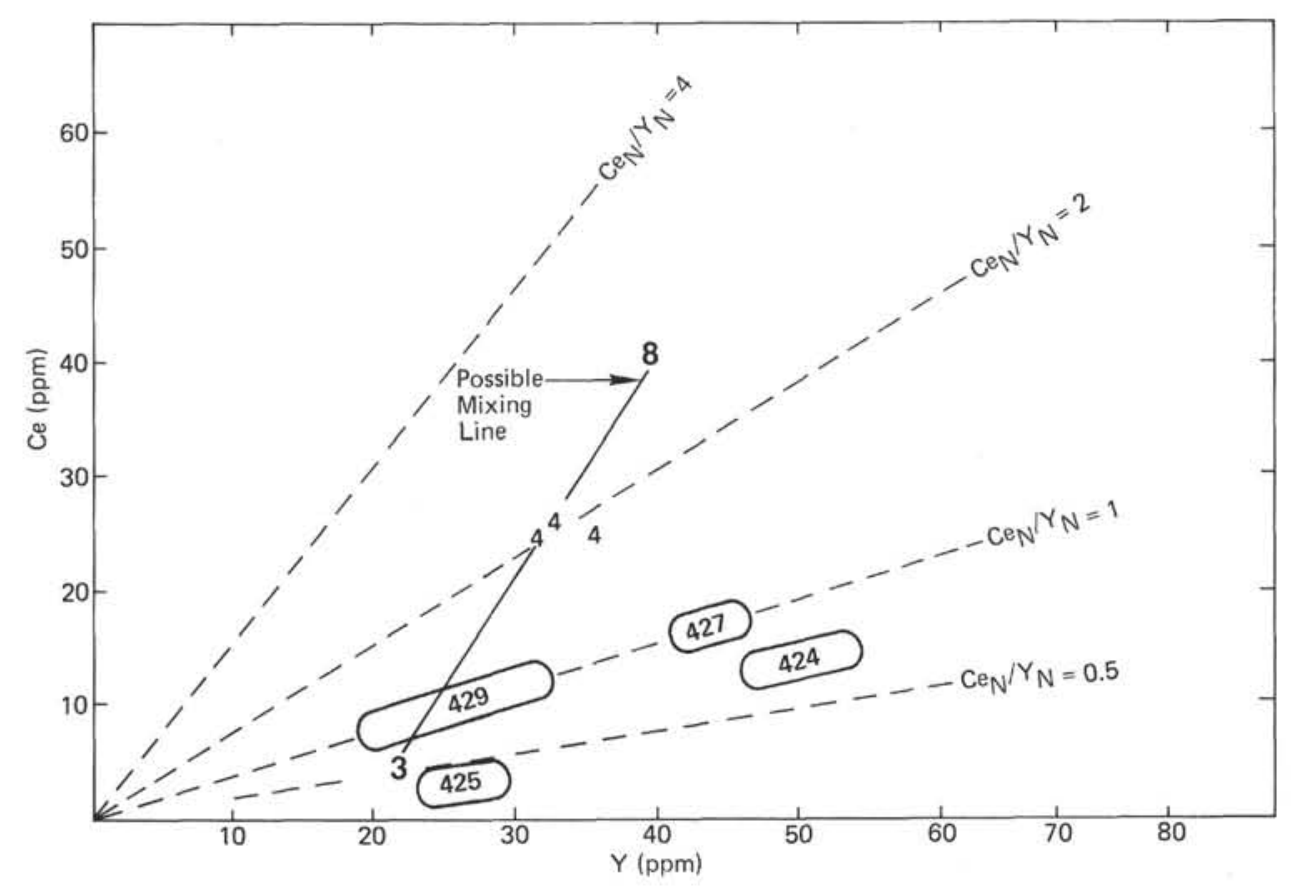

Figure 8. Y versus Ce. Diagram conventions, mixing line, same as in Figure 5.

tholeiites make up much of the ridge whilst less depleted basalts cap its summit-might lie in local elevation of the geotherm as less dense, undepleted mantle-perhaps containing some melt fraction-impinges on the lithosphere from below. Elevation of the geotherm would initiate (or extend) melting in the depleted mantle still above the rising pocket of undepleted material. Volcanism would commence with eruption of tholeiitic basalts. Conduits would later be taken over by ascending melts from the undepleted pocket, and the resulting lavas would cap the primarily tholeiitic ridge. In such a situation, we might expect to see some differences in tholeiitic chemistries along OCP Ridge (we already know they exist in the fracture zone), particularly variations caused by differences in the degree of melting. This is borne out by Figure 5 on which only dredge samples from OCP Ridge (glass counterparts $\mathrm{K}$ and $\mathrm{L}$ ) fall along the trend for "possible partial melting." Site 422 , drilled in the southern moat of OCP Ridge, indeed has two tholeiitic compositions with different $\mathrm{CaO} / \mathrm{Al}_{2} \mathrm{O}_{3}$ (see East Pacific Rise Site Report, this volume, and Humphris et al., this volume), one of which lies closer to the possible partial melt trend of Figure 5. These basalts are not represented by glass compositions, but the whole-rock chemical differences are comparable to those we have already discussed in regard to fracture zone glasses. Humphris et al. (this volume) believe that the Site 422 basalt compositions are within the range of expected 
compositions along a ridge crest (at least compared to the North Atlantic), and propose that lateral diking carried these lavas to OCP Ridge from their original source at the Rise axis. We do not see how this is possible for the "transitional" dredge basalts (dredge DS-4; glass Group K), and favor instead a vertical conduit system for volcanoes along OCP Ridge.

\section{CONCLUSIONS}

We have obtained a suite of natural glass compositions by electron microprobe from basalts of the East Pacific Rise near $9^{\circ} \mathrm{N}$ and the nearby Siqueiros fracture zone. The data allow us to discern two fundamental types of geochemical variation among these lavas. The first type of variation is crystal fractionation. The data indicate that an initial stage of plagioclase-olivine fractionation is followed by plagioclase-clinopyroxene fractionation, leading ultimately to marked enrichment in FeO*, $\mathrm{TiO}_{2}, \mathrm{~K}_{2} \mathrm{O}, \mathrm{P}_{2} \mathrm{O}_{5}$, and low-partition-coefficient trace elements. Although fractionation trends can vary (different proportions of minerals or even different mineral assemblages can segregate from melts), in general, conditions of fractionation must be very similar from place to place and over the past $4 \mathrm{~m}$.y. This is because fractionated (FETI) glass compositions can be so similar that chemical differences are not resolved by the microprobe technique.

The second type of variation results from differences in the degree or depth of melting in the mantle. This leads to a spectrum of magnesian glass compositions of greatest diversity in the Siqueiros fracture zone that cannot be related to each other by mechanisms of shallow crystal fractionation. Instead, graphical techniques and experimental data suggest that this compositional variability results from retention of a calcic mineral, probably clinopyroxene, in the mantle during melting. A similar spectrum of primitive compositions may be supplied to the base of the East Pacific Rise axial magma chamber. It is more likely, however, that conditions of melting are more uniform away from the fracture zone, and that a more uniform parent is supplied. Alternatively or in addition, efficient processes of mixing of primitive melts in the magma chamber may ensure that a uniform average parental composition is produced, from which fractionation processes produce nearly identical ironenriched FETI lavas.

Seamounts near the Rise crest and in the fracture zone can be capped with less depleted transitional and alkalic basalts than the depleted Rise tholeiite suite. This implies that pockets of little-depleted mantle can supply magmas within a few tens of kilometers of the Rise axis.

One of the general conclusions that has come out of the extensive crustal drilling in the North Atlantic is that a spectrum of magma types unrelated by crystal fractionation appears to be supplied to rift axes (e.g., Rhodes et al., 1976, 1978; Byerly and Wright, 1978; Natland, 1978). Differences in the degree and depth of melting, and even quite local source heterogeneities, give each magma batch a distinctive geochemical stamp. A major conclusion of this study is that among the basalts of the East Pacific Rise, underlying an extremely extensive pattern of crystal fractionation leading to iron-enriched basalts (not generally found on the Mid-Atlantic Ridge), there is the same type of variation that exists among basalts on the Mid-Atlantic Ridge. Overall, it is probably not as extensive a variation, and may be more pronounced in fracture zones than between them, but it exists.

The reasons that crystal fractionation is more extensive on this portion of the East Pacific Rise than it is on the Mid-Atlantic Ridge require detailed consideration of the role of axial magma chambers in producing iron-enriched basalt compositions. This is the subject of a companion paper in this volume (Natland, Axial Magma Chambers chapter).

\section{ACKNOWLEDGMENTS}

We are grateful to Rodey Batiza, J. R. Cann, J. W. Hawkins, Jr., Jeffrey Johnson, R. James Kirkpatrick, Bruce R. Rosendahl, and John Tarney for discussions of many of the ideas contained herein, and to some of these gentlemen for assorted comments on various portions of the manuscript. Bruce Rosendahl is especially thanked for his encouragement and cooperation in obtaining samples. Ed Schrader supplied a key sample for glass probe analysis. The cost of trace element analysis was defrayed by DSDP Science activities funds allocated to Leg 54.

\section{REFERENCES}

Anderson, A. T., and Greenland, L. P., 1969. Phosphorus fractionation diagram as a quantitative indicator of crystallization differentiation of basaltic liquids. Geochim. et Cosmochim. Acta, v. 33, p. 493-505.

Arth, J. C., 1976. Behavior of trace elements during magmatic processes - a summary of theoretical models and their applications. J. Res. U.S. Geol. Survey, v. 4, p. 41-47.

Batiza, R., Rosendahl, B. R., and Fisher, R. L., 1977. Evolution of oceanic crust, 3, petrology and chemistry of basalts from the East Pacific Rise and the Siqueiros transform fault. J. Geophys. Res., v. 82, p. 265-276.

Bender, J. F., Hodges, F. N., and Bence, A. E., 1978. Petrogenesis of basalts from the Project FAMOUS area: experimental study of 0 to 15 kbars. Earth Planet. Sci. Lett., v. 41, p. 277-302.

Blanchard, D. P., Rhodes, J. M., Dungan, M. A., Rodgers, K. V., Donaldson, C. H., Brannon, J. C., Jacobs, J. W., and Gibson, E. W., 1976. The Chemistry and Petrology of Basalts from Leg 37 of the Deep-Sea Drilling Project. $J$. Geophys. Res., v. 81, p. 4231-4246.

Bougault, H., Cambon, P., and Toulhoat, H., 1977. X-ray spectrometric analysis of trace elements in rocks; correction for instrumental interferences. $X$-ray Spectrometry, v. 6, p. 66-72.

Bougault, H., Joron, J., and Treuil, M., 1979. Alteration, fractional crystallization, partial melting, mantle properties from trace elements in basalts recovered in the North Atlantic. In Talwani, M., Harrison, C. G., and Hayes, D. E. (Eds.), Deep Drilling Results in the Atlantic Ocean: Ocean Crust, Maurice Ewing Series 2: Washington (American Geophysical Union), p. 352-368.

Bougault, H., Treuil, M., and Joron, J. L., 1978. Trace elements in basalts from $23^{\circ}$ and $36^{\circ}$ in the Atlantic Ocean: fractional crystallization, partial melting, and heterogeneity of the upper mantle. In Melson, W. G., Rabinowitz, P. D., et al., Initial Reports of the Deep Sea Drilling Project, v. 45: 
Washington (U.S. Government Printing Office), p. 493506.

Byerly, G., and Wright, T. L., 1978. Origin of major element trends in DSDP Leg 37 basalts, Mid-Atlantic Ridge. $J$. Volc. Geotherm. Res., v. 3, p. 229-279.

Cann, J. R., 1970. Rb, Sr, Y, Zr, and $\mathrm{Nb}$ in some ocean floor basaltic rocks. Earth Planet. Sci. Lett., v. 19, p. 7-11. , 1970. Manuscript. Analytical details for Rb, Sr, Y, $\mathrm{Zr}$, and $\mathrm{Nb}$ analyses, to accompany the preceding citation, and informal notes on $\mathrm{Rb}, \mathrm{Sr}, \mathrm{Y}, \mathrm{Zr}, \mathrm{Nb}$ determinations by $\mathrm{XRF}$, appended.

Cann, J. R., Tarney, J., Varet, J., and Wood, D. A., 1979. Mantle heterogeneity in the North Atlantic: evidence from Leg 49 geochemistry. In Luyendyk, B. P., Cann, J. R., et al., Initial Reports of the Deep Sea Drilling Project, v. 49: Washington (U.S. Government Printing Office), p. 841850.

Carlson, R. W., Macdougall, J. D., and Lugmair, G. W., 1978. Differential $\mathrm{Sm} / \mathrm{Nd}$ evolution in oceanic basalts. Geophys. Res. Lett., v. 5, p. 229-232.

Clague, D. A., and Bunch, T. E., 1976. Formations of ferrobasalt at East Pacific midocean spreading centers. $J$. Geophys. Res., v. 81, p. 4247-4256.

Engel, A. E. J., and Engel, C. G., 1964. Igneous rocks of the East Pacific Rise. Science, v. 146, p. 477-485.

Engel, A. E. J., Engel, C. G., and Havens, R. G., 1965. Chemical characteristics of oceanic basalts and the upper mantle. Geol. Soc. Am. Bull., v. 76, p. 719-734.

Flanagan, F. J., 1973. 1972 Values for international geochemical reference samples. Geochim. et Cosmochim. Acta, v. 37, p. 1189-1200.

Frey, F. A., Bryan, W. B., and Thompson, G., 1974. Atlantic Ocean floor: Geochemistry and petrology of basalts from Legs 2 and 3 of the Deep Sea Drilling Project. J. Geophys. Res., v. 70, p. 5507-5527.

Fujii, T., Kushiro, I., and Hamuro, K., 1978. Melting relations and viscosity of an abyssal olivine tholeiite. In Melson, W. G., Rabinowitz, P. D., et al., Initial Reports of the Deep Sea Drilling Project, v. 45: Washington (U.S. Government Printing Office), p. 513-516.

Gamble, J. A., 1979. The geochemistry and petrogenesis of dolerites and gabbros from the Tertiary central volcanic complex of Slieve Gullion, North East Ireland. Contrib. Mineral. Petrol., v. 69, p. 5-19.

Gass, I. G., 1970. The evolution of volcanism in the junction area of the Red Sea, Gulf of Aden, and Ethiopian Rifts. Phil. Trans. Roy. Soc. Lond. A., v. 267, p. 369-381.

1972. Proposals concerning the variation of volcanic products and processes within the oceanic environment. Ibid., v. 271, p. 131-140.

Johnson, J., 1979. Transitional basalts and tholeiites from the East Pacific Rise, $9^{\circ}$ N. J. Geophys. Res., v. 84, p. 16351652.

Kay, R., Hubbard, N., and Gast, P. W., 1970. Chemical characteristics of ocean ridge volcanic rocks. Ibid., v. 75, p. 1585-1613.

Kushiro, I., 1968. Compositions of magmas formed by partial zone melting in the earth's upper mantle. Ibid., v. 73, p. 619-634.

, 1975. On the nature of silicate melt and its significance in magma genesis: regularities in the shift of the liquidus boundaries involving olivine, pyroxene, and silica minerals. Am. J. Sci., v. 275, p. 411-431.

Lonsdale, P., 1977. Structural geomorphology of a fastspreading rise crest: the East Pacific Rise near $3^{\circ} 25^{\prime} \mathrm{S}$. Mar. Geophys. Res., v. 3 p. 251-293.
Melson, W. G., 1978. Chemical stratigraphy of Leg 45 basalts: electron probe analyses of glasses. In Melson, W. G., Rabinowitz, P. D., et al., Initial Reports of the Deep Sea Drilling Project, v. 45: Washington (U.S. Government Printing Office), p. 507-512.

Melson, W. G., Vallier, T. L., Wright, T. L., Byerly, G. T., and Nelen, J. A., 1976. Chemical Diversity of Abyssal Volcanic Glass Erupted Along Pacific, Atlantic, and Indian Ocean Sea-Floor Spreading Centers. Geophysical Monograph No. 19: Washington (American Geophysical Union), p. 351-368.

Mohr, P. A., 1971. Ethiopian Rift and plateaus: some volcanic petrochemical differences. J. Geophys. Res., v. 76, p. 1967-1984.

Natland, J., 1978. Comparison of the chemical and magnetic stratigraphy of DSDP Sites 332 and 395. In Melson, W. G., Rabinowitz, P. D. et al., Initial Reports of the Deep Sea Drilling Project, v. 45: Washington, (U.S. Government Office), p. 657-677.

Natland, J., Bougault, H., Fujii, T., Graham, A. L., Melson, W. G., Prosser, E. Rhodes, J. M., and Zolotarev, B., 1978. Chemical data for Sites 395 and 396: analytical procedures and comparison of interlaboratory standards. In Melson, W. G., Rabinowitz, P. D., et al., Initial Reports of the Deep Sea Drilling Project, v. 45: Washington (U.S. Government Printing Office), p. 681-705.

Nielsen, T. F. D., 1978. The Tertiary dike swarms of the Kangerdlugssuaq Area, East Greenland: an example of magmatic development during continental break-up. Contrib. Mineral. Petrol., v. 67, p. 63-78.

Orcutt, J., Kennett, B. and Dorman, L., 1976. Structure of the East Pacific Rise from an ocean bottom seismometer survey. Geophys. J. Roy. Astron. Soc., v. 45, p. 305-320.

Orcutt, J., Kennett, B., Dorman, L., and Prothero, W., 1975. A low velocity underlying a fast-spreading rise crest. $\mathrm{Na}$ ture, v. 256, p. 475-476.

Osborn, E. F., 1959. Role of oxygen pressure in the crystallization and differentiation of basaltic magma. Am. J. Sci., v. 257 , p. $609-647$.

1962. Reaction series for subalkaline igneous rocks based on different oxygen pressure conditions. Am. Mineral., v. 47 , p. $211-226$.

Presnall, D. C., 1969. The geometrical analysis of partial fusion. Am. J. Sci., v. 267 , p. $1178-1194$.

Presnall, D. C., Dixon, J. R., O'Donnell, T. H., and Dixon, S. A., 1979. Generation of mid-ocean ridge tholeiites. $J$. Petrol., v. 20, p. 3-35.

Rhodes, J. M., Blanchard, D. P., Dungan, M. A., Rodgers, K. V., and Brannon, J. C., 1978. Chemistry of Leg 45 Basalts. In Melson, W. G., Rabinowitz, P. D., et al., Initial Reports of the Deep Sea Drilling Project, v. 45: Washington (U.S. Government Printing Office), p. 447-460.

Rhodes, J. M., and Dungan, M. A., 1979. The evolution of ocean floor basaltic magmas. In Talwani, M., Harrison, C. G., and Hayes, D. E. (Eds.), Deep Drilling Results in the Atlantic Ocean: Ocean Crust, Maurice Ewing Series 2: Washington (American Geophysical Union), p. 262-272.

Rosendahl, B. R., 1976. Evolution of oceanic crust 2: constraints, implications and inferences. J. Geophys. Res. v. 81, p. $5305-5314$

Sclater, J. G., Anderson, R. N., and Bell, M. L., 1971. Elevation of ridges and evolution of the central Eastern Pacific. Ibid., v. 76, p. 7888-7915.

Tarney, J., Wood, D. A., Varet, J., Saunders, A. D., and Cann, J. R., 1979. Nature of mantle heterogeneity in the North Atlantic: evidence from Leg 49 basalts. In Talwani, 
M., Harrison, C. G., and Hayes, D. E., (Eds.), Deep Drilling Results in the Atlantic Ocean: Ocean Crust, Maurice Ewing Series 2: Washington (American Geophysical Union), p. 285-301.

Thompson, R. N., Esson, J., and Dunham, A. C., 1972. Major element chemical variation in the Eocene lavas of the Isle of Skye, Scotland. J. Petrol., v. 13, p. 219-253.
Wood, D. A., Tarney, J., Varet, J., Saunders, A. D., Bougault, H., Joron, J. L., Treuil, M., and Cann, J. R., 1979. Geochemistry of basalts drilled in the North Atlantic by IPOD Leg 49: Implications for mantle heterogeneity. Earth Planet. Sci Lett., v. 42, p. 77-97.

Wright, T. L. 1974. Presentation and interpretation of chemical data for igneous rocks. Contrib. Mineral. Petrol., v. 48, p. 233-248. 